\title{
Structural Basis of Inhibition of Human Insulin-Regulated Aminopeptidase (IRAP) by Aryl Sulfonamides
}

\author{
Sudarsana Reddy Vanga, ${ }^{\dagger}$ Jonas Sävmarker, ${ }^{\ddagger}$ Leelee $\mathrm{Ng}^{\perp}$ Mats Larhed, ${ }^{\ddagger}, \S \odot$ Mathias Hallberg, \\ Johan Åqvist, ${ }^{\dagger}$ Anders Hallberg, ${ }^{\ddagger}$ Siew Yeen Chai, ${ }^{*, \perp}$ and Hugo Gutiérrez-de-Terán ${ }^{*}{ }^{\dagger}$ \\ ${ }^{\dagger}$ Department of Cell and Molecular Biology, BMC, Box 596, Uppsala University, SE-751 24 Uppsala, Sweden \\ ${ }^{\ddagger}$ Department of Medicinal Chemistry and ${ }^{\S}$ Science for Life Laboratory, Department of Medicinal Chemistry, Uppsala University, \\ BMC, SE-751 24 Uppsala, Sweden \\ "The Beijer Laboratory, Department of Pharmaceutical Biosciences, Division of Biological Research on Drug Dependence, Uppsala \\ University, BMC, SE-751 23 Uppsala, Sweden \\ ${ }^{\perp}$ Biomedicine Discovery Institute, Department of Physiology, Monash University, Clayton, Victoria 3800, Australia
}

\section{Supporting Information}

ABSTRACT: The insulin-regulated aminopeptidase (IRAP) is a membrane-bound zinc metallopeptidase with many important regulatory functions. It has been demonstrated that inhibition of IRAP by angiotensin IV (Ang IV) and other peptides, as well as more druglike inhibitors, improves cognition in several rodent models. We recently reported a series of aryl sulfonamides as small-molecule IRAP inhibitors and a promising scaffold for pharmacological intervention. We have now expanded with a number of derivatives, report their stability in liver microsomes, and characterize the activity of the whole series in a new assay performed on recombinant human IRAP. Several compounds, such as the new fluorinated derivative 29, present submicromolar affinity and high metabolic stability. Starting from the two binding modes previously proposed for the sulfonamide scaffold, we systematically performed molecular dynamics simulations and binding affinity estimation with the linear interaction energy method for the full compound series. The significant agreement with experimental affinities suggests one of the binding modes, which was further confirmed by the excellent correlation for binding affinity differences between the selected pair of compounds obtained by rigorous free energy perturbation calculations. The new experimental data and the computationally derived structure-activity relationship of the sulfonamide series provide valuable information for further lead optimization of novel IRAP inhibitors.

\section{INTRODUCTION}

It has been known for more than 25 years that angiotensin IV (Ang IV, 1; Figure 1), a degradation product of the vasoactive peptide angiotensin II, enhances memory and learning in rodents after intracerebroventricular administration. ${ }^{1-8}$ Thus, the degradation leads to a bioactive hexapeptide with very different biological activity from that of the parent octapeptide. $^{9,10}$ In 2001, the membrane-bound insulin-regulated aminopeptidase (IRAP, oxytocinase, EC 3.4.11.3) was identified as a binding site for Ang IV, ${ }^{11}$ a potent inhibitor of IRAP, as is LVV-hemorphin-7, which is formed by degradation of $\beta$ globin. ${ }^{12,13}$ The M1 aminopeptidase, IRAP, is found in brain structures associated with cognitive, sensory, and motor functions along with other biological functions such as antigenic peptide generation for MHC Class I for crosspresentation, ${ }^{14,15}$ translocation of GLUT4 $4{ }^{16}$ and oxytocin and vasopressin levels in the brain. The extracellular region of IRAP contains the catalytic site and is highly homologous to two other M1 aminopeptidase family members, endoplasmic reticulum aminopeptidase 1 (ERAP1) and 2(ERAP2). ${ }^{17}$ These three enzymes constitute the so-called antigen processing aminopeptidases anticipatory postural adjustments (APAs), in charge of trim antigenic peptides that will ultimately be used to modulate adaptative response, therefore being potential drug targets for the regulation of immune responses. ${ }^{18}$ Although the poli-inhibition of several APAs is a good starting point in pharmaceutical development in this respect, low selectivity between the three APAs limits the clinical development. From the existing hypotheses to explain the effects of Ang IV in vivo, ${ }^{19-21}$ the one that attracted the most attention is that Ang IV and its analogues enhance cognitive functions through IRAP inhibition, resulting in altered levels of neuropeptides in the brain and/or facilitating glucose uptake in neurons by regulating GLUT4 translocation. ${ }^{21-23}$ The last factor is in line with the well-known enhancement of cognitive performance by glucose $\mathrm{e}^{24}$ and is reinforced by the fact that IRAP inhibitors do not alter glucose handling in normal and diabetic rats. $^{25}$ Endogenous substrates of IRAP, such as macrocyclic

Received: March 29, 2018

Accepted: April 16, 2018

Published: April 25, 2018 
<smiles>CCC(C)[C@H](NC(=O)[C@H](Cc1ccc(O)cc1)NC(=O)[C@@H](N)C(C)C)C(=O)NC(Cc1cnc[nH]1)C(=O)N1C2CCC1C(=O)[C@@H](Cc1ccccc1)NC2=O</smiles>

1, Angiotensin IV (Ang IV)

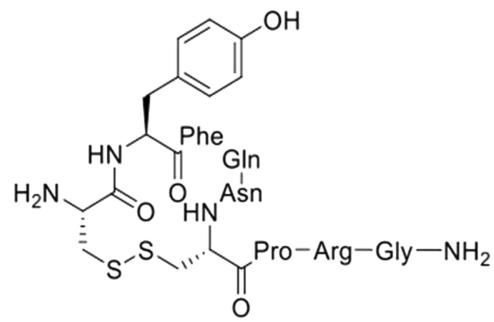

3, Vasopressin

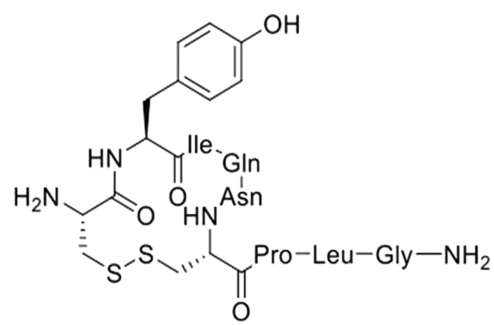

2, Oxytocin<smiles>N[C@@H](CCSSC[C@H](NC(=O)CC(Cc1ccc(O)cc1)NC(=O)[C@H](N)CNCc1ccccc1CC(=O)O)C(=O)O)C(=O)O</smiles>

4, HA-08<smiles>CCCCCC(=O)N[C@@H](Cc1ccc(O)cc1)C(=O)N[C@H](C(=O)NCCCCCC(N)=O)C(C)CC</smiles>

5, Dihexa<smiles>CCOC(=O)C1=C(NC(C)=O)Oc2cc(O)ccc2C1c1cccnc1</smiles>

6. HFI-419<smiles>CCCC[C@H](N)C(=O)Nc1cc(C(=O)NC(Cc2c[nH]c3ccccc23)C(=O)OCc2ccccc2)ccc1N</smiles>

7<smiles>O=S(=O)(Nc1cccc(-c2nnn[nH]2)c1)c1cc(Br)c(Cl)s1</smiles>

8

Figure 1. IRAP inhibitors and substrates: hexapeptide IRAP inhibitor Ang IV (1), macrocyclic IRAP substrates oxytocin (2) and vasopressin (3), macrocyclic IRAP inhibitor HA-08 (4), and cognitive enhancer dihexa (5) that binds to hepatocyte growth factor (HGF). Compounds 6-8 are lowmolecular-weight IRAP inhibitors, not derived from the structure of Ang IV.

peptides oxytocin (2) and vasopressin (3), which encompass a disulfide element adjacent to the cleavage site of the ring system (Figure 1), are known to exert favorable influences on cognitive parameters in the brain. ${ }^{23,26}$

Our labs are engaged in a collaborative program aimed at identifying inhibitors of IRAP as a possible new class of cognitive enhancers. ${ }^{27-31}$ Although several potent linear Ang IV analogues have previously been reported, ${ }^{32-35}$ we have previously reported a large series of cyclic peptides and pseudopeptides; ${ }^{36-41}$ particularly interesting among these were the macrocyclic analogs, mimicking the $\mathrm{N}$-terminal fragment of Ang IV, and the IRAP-specific substrates oxytocin and vasopressin, from which compound HA-08 (compound 4, Figure 1) emerges as a very potent inhibitor of the enzyme $\left(\mathrm{IC}_{50}=8.6 \mathrm{nM} ; K_{\mathrm{i}}=3 \mathrm{nM}\right){ }^{38}$ The biological characterization of this compound demonstrates that it affects the morphology of dendritic spines from rat hippocampal primary cultures and increases the number of stubby/mushroomlike spines, a property associated with improvement of memory and cognitive functions. ${ }^{30}$ However, this and related macrocyclic inhibitors are still peptidic molecules, likely to be associated with pharmacokinetic problems such as limited blood-brain barrier (BBB) permeation. Notably, a dipeptide derivative from Ang IV, known as Dihexa (compound 5, Figure 1), which increases dendritic spine density and serves as a powerful cognitive enhancer in animal models, is able to cross the BBB. However, it remains unclear whether this molecule is an IRAP inhibitor, and to date, there is only evidence that this peptide binds to the hepatocyte growth factor (HGF). ${ }^{42,43}$

The first series of druglike IRAP inhibitors reported comprises a benzopyran scaffold. The benzopyran, HFI-419 (Compound 6, Figure 1), represents one example of the promising compounds from this class. ${ }^{27,44}$ The inhibitors from the HFI series were identified through in silico screening and 
Table 1. Inhibitory Activities and Metabolic Stability of the Sulfonamide Series in IRAP

\begin{tabular}{|c|c|c|c|c|c|}
\hline Compound & Structure & $\begin{array}{l}\text { IC }_{50} \text { IRAP }(\mu M)^{a} \\
t^{a} 12 \text { HLM }(M L M)^{b}\end{array}$ & Compound & Structure & $\begin{array}{l}\text { IC }_{50} \operatorname{IRAP}(\mu \mathrm{M})^{\mathrm{a}} \\
\mathrm{t}^{1 / 2} \mathrm{HLM}(\mathrm{MLM})^{\mathrm{b}}\end{array}$ \\
\hline 8 & & $\begin{array}{c}1.1 \pm 0.1(3) \\
\mathrm{ND}\end{array}$ & 22 & & $\begin{array}{c}7.5 \pm 1.0(3) \\
\mathrm{ND}\end{array}$ \\
\hline 9 & & $\begin{array}{c}>1000 \\
\text { ND }\end{array}$ & 23 & & $\begin{array}{c}5.5 \pm 0.5(4) \\
\mathrm{ND}\end{array}$ \\
\hline 10 & & $\begin{array}{c}>1000 \\
\text { ND }\end{array}$ & 24 & & $\begin{array}{c}1.4 \pm 0.1(4) \\
\text { ND }\end{array}$ \\
\hline 11 & & $\begin{array}{c}11.8 \pm 2.3(4) \\
\mathrm{ND}\end{array}$ & 25 & & $\begin{array}{l}0.7 \pm 0.0(3) \\
2(50)\end{array}$ \\
\hline 12 & & $\begin{array}{c}>1000(2) \\
\text { ND }\end{array}$ & 26 & & $\begin{array}{c}0.5 \pm 0.1(4) \\
88(48)\end{array}$ \\
\hline 13 & & $\begin{array}{c}0.8 \pm 0.1(4) \\
\text { ND }\end{array}$ & 27 & & $\begin{array}{c}1.2 \pm 0.4(4) \\
600(192)\end{array}$ \\
\hline 14 & & $\begin{array}{c}>100(3) \\
\text { ND }\end{array}$ & 28 & & $\begin{array}{c}4.1 \pm 0.9(3) \\
600(535)\end{array}$ \\
\hline 15 & & $\begin{array}{c}>100(3) \\
\text { ND }\end{array}$ & 29 & & $\begin{array}{l}0.8 \pm 0.2(3) \\
\quad 600(35)\end{array}$ \\
\hline 16 & & $\begin{array}{c}14.5 \pm 14.1(3) \\
\mathrm{ND}\end{array}$ & 30 & & $\begin{array}{c}2.3 \pm 0.4(3) \\
4(38)\end{array}$ \\
\hline 17 & & $\begin{array}{c}5.9 \pm 1.6(3) \\
\text { ND }\end{array}$ & 31 & & $\begin{array}{c}2.3 \pm 0.2(3) \\
600(133)\end{array}$ \\
\hline 18 & & $\begin{array}{c}10.9 \pm 1.9(3) \\
\mathrm{ND}\end{array}$ & 32 & & $\begin{array}{c}7.5 \pm 0.3(3) \\
600(174)\end{array}$ \\
\hline 19 & & $\begin{array}{c}12.7 \pm 3.2(3) \\
\mathrm{ND}\end{array}$ & 33 & & $\begin{array}{c}14.097 \pm 0.936(3) \\
600(72)\end{array}$ \\
\hline 20 & & $\begin{array}{c}>1000(3) \\
\text { ND }\end{array}$ & 34 & & $\begin{array}{l}12.1 \pm 3.4(4) \\
600(346)\end{array}$ \\
\hline 21 & & $\begin{array}{c}0.4 \pm 0.1(4) \\
200(81)\end{array}$ & & & \\
\hline
\end{tabular}

${ }^{a} \mathrm{IC}_{50}$ was evaluated in an enzyme assay comprising recombinant human IRAP, transiently transfected in HEK293 cells, where a structural analog of 6 was used as control exhibiting an $\mathrm{IC}_{50}$ value of $5.29 \mu \mathrm{M}$. ${ }^{b}$ Stabilities $\left(t_{1 / 2}, \mathrm{~min}\right)$ in human liver microsomes (HLMs) and mouse liver microsomes (MLMs) were measured for compounds 21 and 25-34. $\mathrm{ND}=$ not determined. 
Scheme 1. Reagents: DCM, Pyridine; $25^{\circ} \mathrm{C}, 16 \mathrm{~h}$

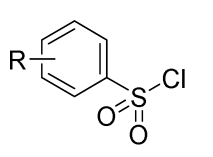

35<smiles>Nc1cccc(-c2nnn[nH]2)c1</smiles>

36

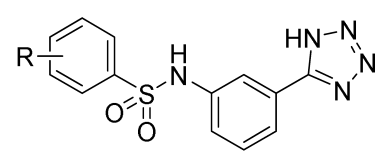

27-34 are proven to be effective as cognitive enhancers in both normal and memory-deficit rat models. ${ }^{44-46}$ The 3,4-diaminobenzoic acid derivative 7 is an example of another class of compounds able to efficiently inhibit IRAP, showing in this case moderate selectivity versus ERAP1 and ERAP2. ${ }^{47}$ More recently, very potent IRAP inhibitors relying on efficient zinc coordination through a phosphinic group were disclosed. ${ }^{48,49}$

We previously screened 10500 low-molecular-weight druglike compounds in an enzyme inhibition assay with IRAP from Chinese hamster ovary (CHO) cells, ${ }^{50}$ from which compound $\mathbf{8}$ and related sulfonamides (Figure 1) were identified as a novel class of druglike IRAP inhibitors. ${ }^{51}$ Two analogs from this series were further evaluated and found to alter the morphology and increase the density of dendritic spines of hippocampal cells from mice. ${ }^{31}$ By means of exhaustive docking and free energy calculations, we identified two binding orientations compatible with the experimental data there reported. ${ }^{31}$ Encouraged by these results, we herein expanded the sulfonamide collection with a series of fluoro atom substituted derivatives and report the capacity of the resulting expanded series $(\mathbf{8}-\mathbf{3 4}$, Table 1$)$ to inhibit recombinant human IRAP expressed in membranes of human embryonic kidney cells (HEK293). The fluorinated series exhibits high metabolic stability in microsomes and encompasses compounds with submicromolar affinity. The binding modes previously identified were thoroughly examined here with molecular dynamics (MD)-related methods for binding affinity estimation for the whole series of aryl sulfonamides. Thus, absolute binding free energies were obtained for each binding mode with the linear interaction energy (LIE) method, followed by calculations of relative binding free energies between six pairs of compounds using free energy perturbation (FEP) protocols. The results of this computational analysis clearly identify one binding mode, which specifically explains the structure-activity relationship (SAR) data and allows for elucidation of the molecular details involved in ligand binding to the protease.

\section{RESULTS AND DISCUSSION}

Chemistry. Compounds 8-26 were prepared according to methods previously described. ${ }^{51,52}$ Trichloro compound 27 and fluoro compounds 28-34 were prepared from 3-amino phenyltetrazole and the corresponding arylsulfonyl chloride to deliver the aryl sulfonamides, as shown in Scheme 1.

IRAP Inhibition and SAR. The ability of compounds 8-34 of inhibiting the catalytic activity of recombinant human IRAP was examined in transiently transfected HEK293 cells; the results are summarized in Table 1 . The data confirms the same SAR trend as previously observed from a smaller series of sulfonamides tested in $\mathrm{CHO}$ cells, that is, containing the hamster enzyme, ${ }^{51}$ although somewhat lower $\mathrm{IC}_{50}$ values were encountered with the human IRAP assay (Figure S1, Supporting Information). Sulfonamides 25 and 26, which were previously shown to enhance the density of dendritic spines in primary hippocampal neuron cultures from mice, ${ }^{31}$ show $\mathrm{IC}_{50}$ values of $0.74 \mu \mathrm{M}$ (vs $3.1 \mu \mathrm{M}$ in $\mathrm{CHO}$ cells) and
$0.54 \mu \mathrm{M}$ (vs $2.9 \mu \mathrm{M}$ ), respectively. Among the general SAR observations, the negative charge of the tetrazole ring seems essential for IRAP inhibition because methylation of the acidic $\mathrm{NH}$ position was deleterious for activity (cf. 8 and 9). A similar negative effect was observed by replacement of the tetrazole by a methylamide group (cf. 10 and 9). The integrity of the sulfonamide linker seems essential for IRAP affinity, as suggested by the 10 -fold drop in binding affinity after methylation of the acidic NH group (cf. 8 and 11) or the complete lack of inhibitory activity of the corresponding amidederivative 12. A thiophene ring is admitted only if it is halogenated, as is the case of dichloro substituted inhibitor 13, showing submicromolar activity, as opposed to inactive, unsubstituted derivative 14. Pyridine derivative 15 is also devoid of IRAP activity, whereas the benzene derivative, which also displayed no inhibitory activity applying the previous assay, is here shown to moderately inhibit the human IRAP $\left(\mathrm{IC}_{50}=\right.$ 14.5 $\mu \mathrm{M})$. Bicyclic derivatives are well tolerated; see compounds 17, 18, 19, and particularly submicromolar benzoxadiazole $\mathbf{2 1}$. However, biphenyl derivative $\mathbf{2 0}$ is totally inactive, indicating some restriction in the binding cavity accommodating this substitution. To assess the halogenation on the phenyl ring, the previous set of derivatives of compound 16 (containing 22-26, all of which show promising $\mathrm{IC}_{50}$ values below $10 \mu \mathrm{M}$ ) was here expanded with compounds 27-34. As expected, most compounds show an important improvement compared to that of the reference unsubstituted 16, with compounds 25, 26, and 29 showing the same submicromolar potency as that of benzoxadiazole $\mathbf{2 1}$.

Stability in Liver Microsomes. The most potent sulfonamides, together with the new series of derivatives (21, 25-34), were selected for characterization of their stability against oxidative metabolism. Stability was assessed using liver microsomes from human liver (HLM) and from mouse (MLM) applying a protocol previously reported. ${ }^{53}$ All compounds evaluated exhibited a high stability in the microsome assays with the exception of 25 and 30, which were degraded fast in HLM ( $t_{1 / 2}$ of 2 and 4 min, respectively), as shown in Table 1. This observation can be most likely attributed to a human enzyme-specific benzylic oxidation of the para methyl groups of $\mathbf{2 5}$ and $\mathbf{3 0}$, and the meta methyl derivative 31 was significantly less prone to decomposition $\left(t_{1 / 2}\right.$ $=600 \mathrm{~min}$ ).

MD and LIE Calculations. In a previous attempt to understand the binding mode of inhibitors 21, 25, and 26, a pool of possible binding orientations was initially generated by exhaustive docking of compound 26. Each pose was subject to MD simulations, coupled to binding affinity estimation with the LIE method ${ }^{54,55}$ for the three compounds in the series. Two alternative binding modes, pose $\mathrm{A}$ and pose $\mathrm{B}$, were compatible with the experimental ranking in affinities within this limited subset. ${ }^{31}$ One of the sulfone oxygens coordinates the $\mathrm{Zn}^{2+}$ ion in both binding modes, which otherwise are flipped with respect to each other in a way that the position of the aryl (or heteroaryl) and phenyltetrazole moieties are switched between 


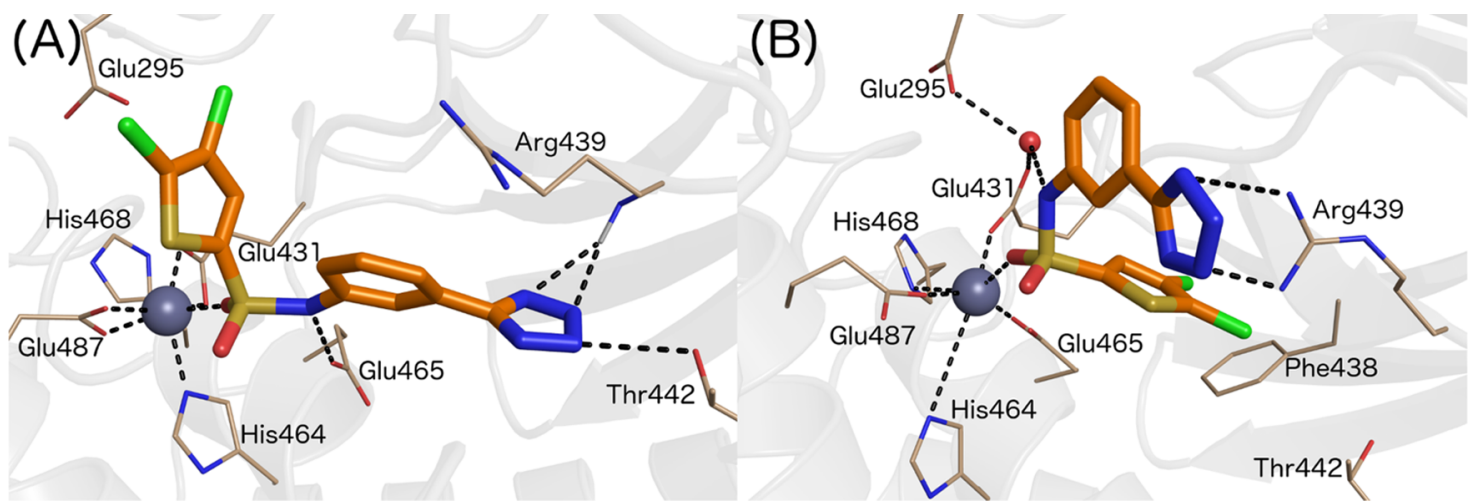

Figure 2. Binding modes of compound 13 (orange) in the enzymatic cleft of human IRAP. (A) pose A; (B) pose B. $\mathrm{Zn}^{2+}$ and water molecules are shown as gray and red spheres, respectively, and chlorine atoms are represented in green. All of the figures shown are from 2 ns MD average structures.

them (Figure 2). We herein built every complex consisting of the 27 sulfonamides (compounds 8-34 in Table 1) in each of the two binding poses (A and B; see Figure 2) and performed a similar exploration with MD sampling coupled to the LIE estimation of binding affinities. Inactive compounds $\mathbf{9}$ and $\mathbf{1 0}$ were not considered because they are the only neural ones in the otherwise charged series of compounds (see below). All simulated compounds were stable in each of the two poses, where the key interactions of the sulfone oxygen, $-\mathrm{NH}$, and tetrazole groups described below were maintained for the whole series in different independent replicate $\mathrm{MD}$ simulations. In pose $\mathrm{A}$ (Figure $2 \mathrm{~A}$ ), the ligand is further stabilized by interactions between its $-\mathrm{NH}$ group and Glu465. The tetrazole ring is accommodated in the cavity defined by the hinge loop between residues 438 and 443, dominated by polar interaction with the backbone of Arg439 and the side chain of Thr442. The heteroaryl substituent is facing the GAMEN loop $\left({ }^{428} \mathrm{Gly}-\mathrm{Ala}-\right.$ Met-Glu-Asn ${ }^{432}$ ), a key structural motif that remains open during the MD simulations of the crystal structure considered, ${ }^{30,56}$ allowing accommodation of most substitutions explored in the series. The alternate pose B (Figure 2B) places the heteroaryl group close to the 438-443 loop, and the tetrazole is coordinated to Arg439. This area is relatively solvent exposed, and the aforementioned interaction is sometimes bridged via a water molecule in the MD simulations. Additionally, the - $\mathrm{NH}$ group of the sulfonamide in this binding mode interacts with the carboxylate groups of Glu295 and Glu431 via a water molecule.

Binding free energies estimated with the LIE methodology are reported in Table 2 , and the values obtained in each pose are compared to the experimental values from HEK293 cells, as extracted from Table 1. Owing to the strong electrostatic ligand interactions with the $\mathrm{Zn}^{2+}$ ion, which is very sensitive to given force field parameters, it was found necessary in previous LIE calculations to empirically determine the electrostatic scaling factor $\beta^{30,31,57}$ The same situation was, for example, encountered with saccharide binding to lectins in which the ligand interactions were dominated by coordination to calcium ions. ${ }^{57}$ The earlier derived $\beta$-value of 0.19 for IRAP ligands ${ }^{30,31}$ was, however, based on MD simulations with only three peptidic inhibitors. Still, it led to a good correlation between MD sampled energies-using both poses $\mathrm{A}$ and $\mathrm{B}$ - and $\mathrm{CHO}$ experimental affinities for the three sulfonamides recently characterized $(21,25$, and 26). In the present series, 21 out of the 27 compounds have experimentally determined $\mathrm{IC}_{50}$ values,
Table 2. LIE-Calculated and Experimental Binding Free Energies of Sulfonamide Inhibitors in Complex with IRAP $^{a, b}$

\begin{tabular}{|c|c|c|c|}
\hline \multirow[b]{2}{*}{ ligand } & \multicolumn{2}{|c|}{$\operatorname{LIE}^{b}$} & \multirow[b]{2}{*}{ experimental from $\mathrm{IC}_{50}$} \\
\hline & pose $A^{c}$ & pose $B^{d}$ & \\
\hline 8 & $-7.70 \pm 0.1$ & $-8.08 \pm 0.2$ & $-8.10 \pm 0.1$ \\
\hline 11 & $-8.44 \pm 0.4$ & $-7.54 \pm 0.2$ & $-6.72 \pm 0.1$ \\
\hline 12 & $-8.22 \pm 0.2$ & $-7.85 \pm 0.2$ & $>-4.09^{e}$ \\
\hline 13 & $-7.64 \pm 0.1$ & $-8.20 \pm 0.1$ & $-8.32 \pm 0.1$ \\
\hline 14 & $-7.44 \pm 0.2$ & $-7.15 \pm 0.2$ & $>-5.45^{f}$ \\
\hline 15 & $-7.04 \pm 0.2$ & $-7.04 \pm 0.2$ & $>-5.45^{f}$ \\
\hline 16 & $-6.88 \pm 0.2$ & $-7.38 \pm 0.2$ & $-6.60 \pm 1.3$ \\
\hline 17 & $-7.57 \pm 0.2$ & $-7.51 \pm 0.1$ & $-7.13 \pm 0.2$ \\
\hline 18 & $-7.35 \pm 0.3$ & $-7.48 \pm 0.1$ & $-6.76 \pm 0.1$ \\
\hline 19 & $-7.46 \pm 0.3$ & $-7.12 \pm 0.1$ & $-6.67 \pm 0.2$ \\
\hline 20 & $-7.66 \pm 0.2$ & $-7.14 \pm 0.2$ & $>-4.09^{e}$ \\
\hline 21 & $-8.08 \pm 0.2$ & $-8.52 \pm 0.2$ & $-8.70 \pm 0.1$ \\
\hline 22 & $-7.62 \pm 0.2$ & $-7.44 \pm 0.1$ & $-6.98 \pm 0.1$ \\
\hline 23 & $-7.26 \pm 0.1$ & $-7.05 \pm 0.1$ & $-7.17 \pm 0.1$ \\
\hline 24 & $-7.64 \pm 0.2$ & $-7.81 \pm 0.1$ & $-7.97 \pm 0.1$ \\
\hline 25 & $-7.43 \pm 0.1$ & $-7.34 \pm 0.1$ & $-8.36 \pm 0.0$ \\
\hline 26 & $-7.51 \pm 0.1$ & $-7.49 \pm 0.2$ & $-8.54 \pm 0.1$ \\
\hline 27 & $-8.04 \pm 0.1$ & $-8.39 \pm 0.1$ & $-8.07 \pm 0.2$ \\
\hline 28 & $-7.45 \pm 0.2$ & $-6.89 \pm 0.1$ & $-7.34 \pm 0.1$ \\
\hline 29 & $-7.34 \pm 0.3$ & $-7.25 \pm 0.2$ & $-8.29 \pm 0.1$ \\
\hline 30 & $-7.43 \pm 0.1$ & $-7.47 \pm 0.1$ & $-7.67 \pm 0.1$ \\
\hline 31 & $-7.78 \pm 0.2$ & $-8.00 \pm 0.2$ & $-7.67 \pm 0.0$ \\
\hline 32 & $-7.77 \pm 0.1$ & $-6.96 \pm 0.1$ & $-6.99 \pm 0.0$ \\
\hline 33 & $-6.91 \pm 0.2$ & $-6.41 \pm 0.2$ & $-6.61 \pm 0.0$ \\
\hline 34 & $-6.94 \pm 0.3$ & $-6.99 \pm 0.2$ & $-6.70 \pm 0.2$ \\
\hline
\end{tabular}

${ }^{a}$ Calculations based on pose $A$ and pose $B .{ }^{b}$ All energies are in kcal/ mol, with standard error of the mean (SEM) for calculated (replicate simulations) and experimental (independent experiments) values. ${ }^{c}$ Optimized LIE model, with $\alpha=0.181, \beta=0.1, \gamma=-6.43$ for pose $A$. ${ }^{d} \alpha=0.181, \beta=0.07$, and $\gamma=-4.89$ for pose $B$. ${ }^{e}$ Experimental $\mathrm{IC}_{50}$ is $>1000 \mu \mathrm{M},{ }^{f}$ Experimental $\mathrm{IC}_{50}$ is $>100 \mu \mathrm{M}$. Neutral compounds 9-10, which are also inactive, are excluded from the table as they do not obey our LIE parameterization derived for charged compounds.

whereas compounds $9,10,12$, and 20 exhibit $\mathrm{IC}_{50}$ values $>1000 \mu \mathrm{M}$ and compounds 14-15 have $\mathrm{IC}_{50}>100 \mu \mathrm{M}$. Hence, we selected this subset of $\mathbf{2 1}$ compounds in each binding mode ( $\mathrm{A}$ and $\mathrm{B}$ ) to optimize the LIE model by independent fitting of the $\beta$ and $\gamma$ parameters, while using the standard value of $\alpha=0.181$ (free parameterization of the last 

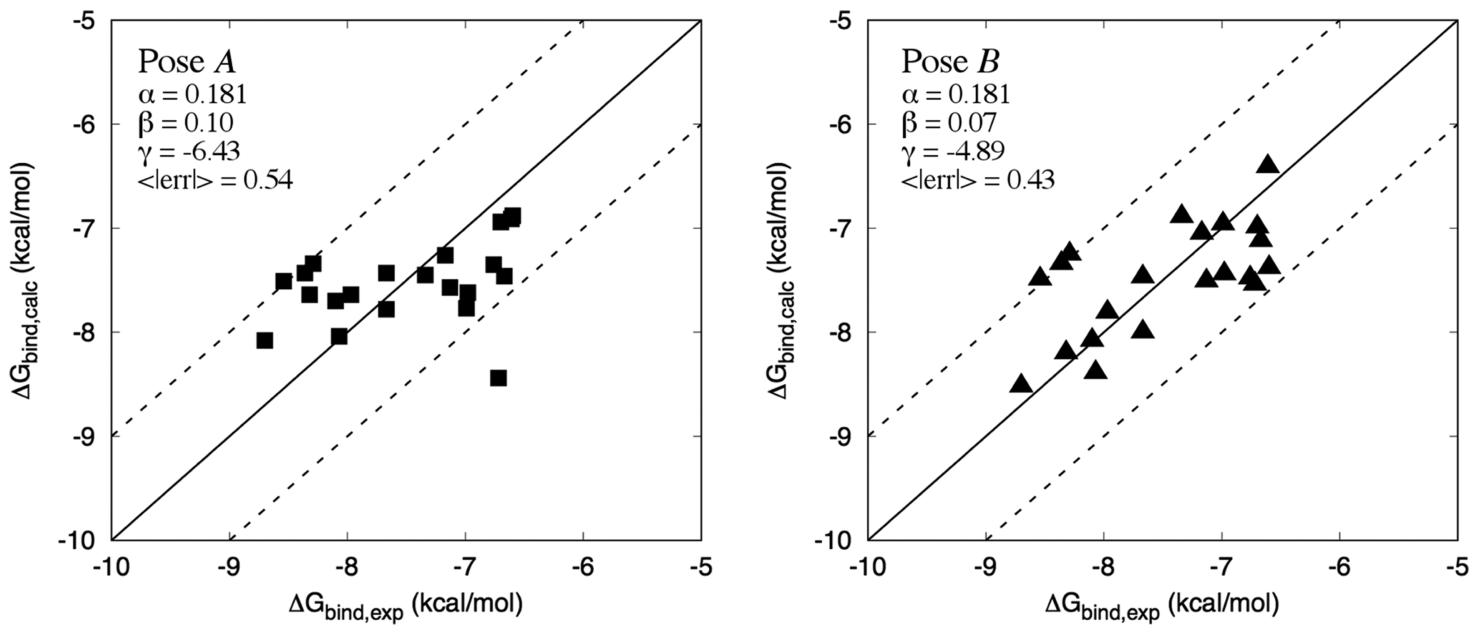

Figure 3. Scatter plot of LIE-calculated (A, pose $A ; \mathrm{B}$, pose $B$ ) and experimental binding free energies of the sulfonamide series. The plots contain 21 data points, as the six compounds without a measured $\mathrm{IC}_{50}$ value are excluded from this quantitative evaluation.

Table 3. Experimental and Calculated (FEP) Relative Binding Free Energies between Pairs of Sulfonamide Ligands

\begin{tabular}{ccrc} 
& \multicolumn{2}{c}{$\Delta \Delta G_{\text {calc }}(\mathrm{kcal} / \mathrm{mol} \pm \mathrm{SEM})$} & \multicolumn{1}{c}{$\Delta \Delta G_{\text {exp }}(\mathrm{kcal} / \mathrm{mol} \pm \mathrm{SEM})^{b}$} \\
\cline { 2 - 3 } $\operatorname{transformation}^{a} \mathrm{LIG}_{\mathrm{A}} \rightarrow \mathrm{LIG}_{\mathrm{B}}$ & pose A & pose B & $<-4.01 \pm 0.0^{c}$ \\
$\mathbf{9} \rightarrow \mathbf{8}$ & $5.40 \pm 0.4$ & $-4.86 \pm 0.2$ & $>4.01 \pm 0.0^{c}$ \\
$\mathbf{8} \rightarrow \mathbf{1 2}$ & $8.80 \pm 1.0$ & $6.58 \pm 1.6$ & $-1.60 \pm 0.1$ \\
$\mathbf{1 1} \rightarrow \mathbf{1 3}$ & $2.10 \pm 0.3$ & $-1.69 \pm 0.1$ & $<2.87 \pm 0.1^{c}$ \\
$\mathbf{1 3} \rightarrow \mathbf{1 4}$ & $-1.41 \pm 0.5$ & $2.67 \pm 0.6$ & $-0.19 \pm 0.1$ \\
$\mathbf{2 2} \rightarrow \mathbf{2 3}$ & $1.28 \pm 0.1$ & $-0.91 \pm 0.2$ & $<-2.51 \pm 1.3^{c}$
\end{tabular}

${ }^{a}$ The arrow depicts the direction of the transformation, as set up in the corresponding FEP simulation, which determines the sign of the corresponding $\Delta \Delta G_{\text {bind. }}{ }^{b}$ The relative binding free energies $\left(\Delta \Delta G_{\text {exp }}\right)$ were calculated from experimentally determined $\mathrm{IC}_{50}$ values using the relation $\Delta \Delta G_{\text {bind,exp }}^{\text {o }}=R T \ln \left(\frac{\mathrm{IC}_{50}(\mathrm{~B})}{\mathrm{IC}_{50}(\mathrm{~A})}\right) \cdot{ }^{c}$ No experimental value could be determined (i.e., $\mathrm{IC}_{50}>100 \mu \mathrm{M}$ ), and the calculated $\Delta \Delta G_{\text {exp }}$ represents the detection threshold.

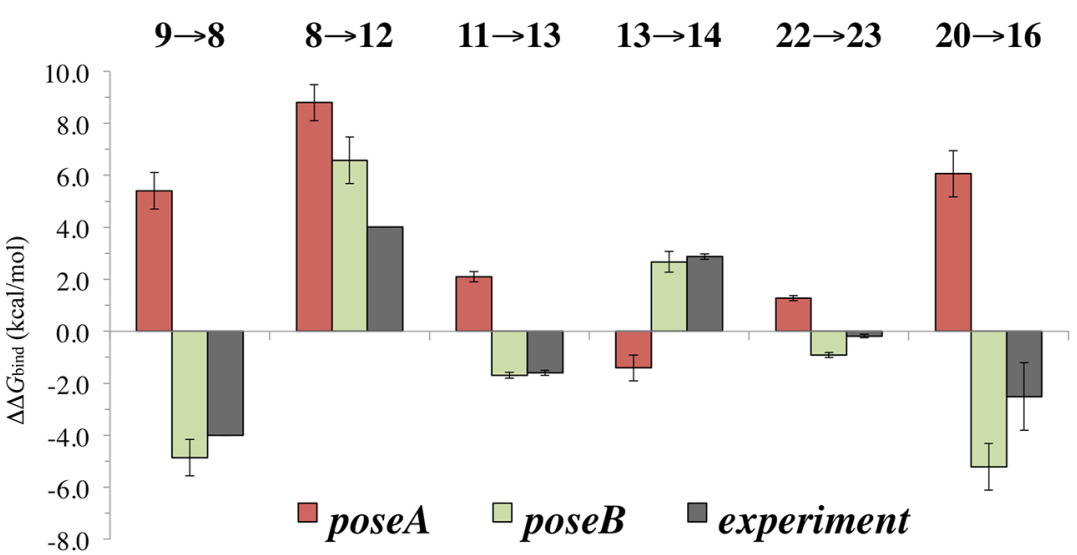

Figure 4. Bar diagram showing relative binding free energies $\left(\Delta \Delta G_{\text {bind }}\right)$ of six pairs of compounds, calculated in poses $A$ and $B$ and compared to the corresponding experimental values). Energies are in $\mathrm{kcal} / \mathrm{mol}$, and errors bars denote SEM.

parameter did not improve the statistics). Figure 3 shows the correlation between calculated and experimental affinities for the two binding modes, together with the corresponding optimized parameters and the calculated mean unassigned error (MUE). A similarly low value of $\beta \approx 0.1$ is obtained in the two binding modes, which is likely due to the strong $\mathrm{Zn}^{2+}$ interactions as outlined above. Notably, the offset parameter, $\gamma$, which is only a constant (in $\mathrm{kcal} / \mathrm{mol}$ ) that does not affect relative binding free energies, is more negative for pose $A$ than pose $\mathrm{B}$. This indeed reflects overall more favorable interaction energies in the latter pose, which is particularly due to the electrostatic component of the binding free energy $\left(\Delta G_{\mathrm{el}}\right.$; see Supporting Information Tables S1 and S2). Further, a modest correlation between $\Delta G_{\text {el,calc }}$ and $\Delta G_{\text {obs }}$ is only observed for pose $\mathrm{B}$, which is indicative of more specific electrostatic interactions as compared to that for pose A (see Supporting Information Figure S2). The two models show reasonably good statistical performance, with MUEs of 0.54 (A) and 0.43 (B) $\mathrm{kcal} / \mathrm{mol}$. The slightly better performance for pose $\mathrm{B}$ is, however, barely significant considering that the experimental 

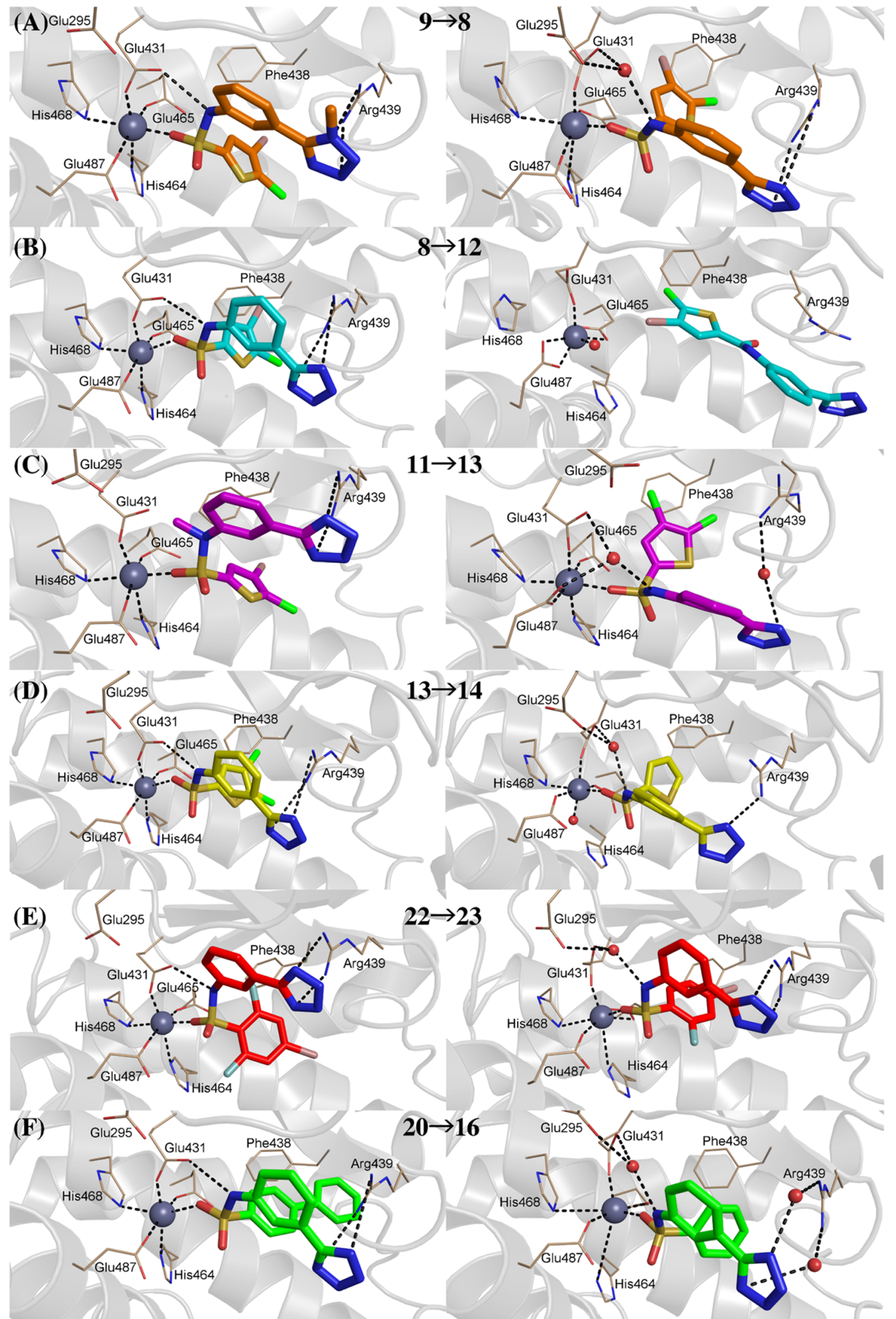


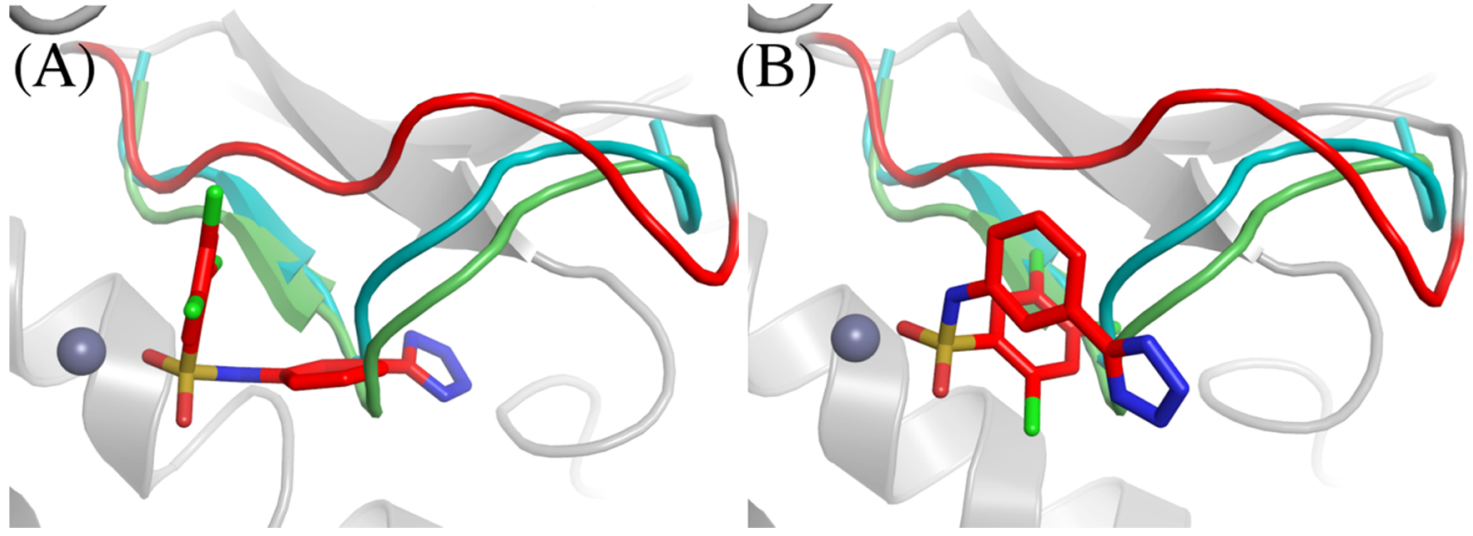

Figure 6. Binding modes of compound 26 (red sticks) in IRAP (gray cartoon) in pose $A$ (A) and pose $B$ (B). GAMEN loop of IRAP highlighted in red and overlaid with that of homologous proteases: APN (PDB code 4FYQ light green) and LTA4H (PDB code 2VJ8, cyan), which show a predicted steric clash with the sulfonamide in either binding mode. $\mathrm{Zn}^{2+}$ is shown as gray sphere.

compared to $R=0.36$ for pose $A$ ). However, none of the models can completely capture the low affinity of nonbinders $12,14,15$, and 20 , which are overestimated in the two models (Table 2).

Free Energy Perturbation Calculations. To confirm the indication of the LIE models that marginally favor pose B and further investigate the reasons for the low affinity of nonbinders, we designed a set of free energy perturbation (FEP) transformations for selected pairs of ligands. With this approach, one can estimate the relative binding free energies $(\Delta \Delta G)$ between pairs of compounds and compare with the corresponding experimental shifts in binding affinities. A total of 10 ligands were considered in six pairs of FEP transformations, which were also carried out in parallel in both binding modes. These include nonbinders 9, 12, 14, and 20, which were selected to cover different structural changes affecting the affinity within the series. The results of the FEP calculations are summarized in Table 3 and Figure 4. The drastic effect observed by methylation of the tetrazole ring was examined by performing the transformation $8 \leftrightarrow 9$. In this case, pose $B$ reproduces the experimental effect very accurately, which can be related to the loss of interactions with Arg439, leading to major rearrangements of the ligand (Figure 5). In contrast, in pose $A$, the tetrazole ring is buried toward the 438443 loop, and the effect of methylation and the corresponding charge neutralization is instead predicted to be favorable for the affinity (Supporting Information Figure S3). Two pairs of perturbations were carried out to examine the drop of enzyme inhibition observed by variations of the sulfonamide linker: replacement of sulfonamide by an amide $(8 \leftrightarrow 12)$ and methylation of the $-\mathrm{NH}$ group $(13 \leftrightarrow 11)$. In the former case, the loss of binding affinity is due to the amide adopting a more energetically favorable trans conformation, leading to the loss of interactions in both poses $A$ and $B$ (Figure 5B). More subtle and specific is the effect of methylation in compound $\mathbf{1 1}$ compared to that in unmethylated derivative 13. The experimental 10-fold drop in affinity is only observed in the simulations of pose $B$ (Table 3 and Figure 4) and can be assigned to the loss of the interaction between $\mathrm{NH}$ and Glu431 conserved in this pose (Figure 5C). Note that in this case, we also evaluated the negligible effect on binding affinity of the $\mathrm{Br}$ / $\mathrm{Cl}$ transformation between this pair, correctly reproduced in the model of pose $B$. The remaining three FEP transformations examined the impact of modifications of the aryl moiety. The positive effect of halogenation on the thiophene (transformation $14 \leftrightarrow 13)$ or the benzene rings $(23 \leftrightarrow 22)$ was also exclusively reproduced in pose $B$ (Table 3 and Figure 4). In the case of thiophene, the unsubstituted compound (14) is a nonbinder, in contrast to the sub-micrometer inhibitor bearing a 3,4-dichloro-2-thiophene (13). Notably, this effect is specifically captured by the FEP simulation in pose $B$, but was underpredicted in the corresponding LIE model. The FEP calculations of pose $B$ are sensitive enough to detect the milder effect of fluorination in the orthoposition of the benzene ring $(23 \leftrightarrow 22)$, which is explained by the optimized interactions of the aryl group with residues in the 438-443 loop. Finally, an intriguing transformation not captured in the LIE models referred to the introduction of a biphenyl ring in compound $\mathbf{1 6}$ to yield compound 20, which led to an experimental loss of any inhibitory activity. This effect is indeed reproduced in the corresponding FEP simulation $(\mathbf{1 6} \leftrightarrow \mathbf{2 0})$ in pose $B$, where the substitution leads to a suboptimal fitting of the biphenyl in the narrow cavity defined by the 438-443 loop (Figure 5F), which provides further evidence of the specificity of this binding model in explaining the SAR of the current series.

IRAP Selectivity of Sulfonamides. We have previously reported that sulfonamides $\mathbf{2 1}, \mathbf{2 5}$, and 26 are specific IRAP inhibitors, with much lower efficacy in inhibiting the activity of the homologous enzymes, aminopeptidase $\mathrm{N}$ (APN) and leukotriene A4 hydrolase (LTA4H). ${ }^{31}$ Our extended binding mode analysis of the whole series of sulfonamides on IRAP allows for interpretation of the selectivity. Figure 6 shows a superposition of the two IRAP-26 complexes (pose $A$ and pose $B$ ) with the crystal structures of APN (PDB code $4 \mathrm{FYQ})^{58}$ and LTA4H (PDB code 2VJ8). ${ }^{59}$ The optimal complementarity between inhibitor 26 and the GAMEN loop of IRAP, which is maintained along the whole sulfonamide series, is in stark contrast to the GAMEN loop conformation found in APN and LTA4H. The conformation of the loop in the latter enzymes is clearly incompatible with the binding modes discussed herein. However, a similar conformation of the GAMEN loop was also observed in the latest crystal structure of IRAP in complex with the phosphinic derivatives. Although this may be a property of that particular inhibitor, one should not rule out the possibility that all potent inhibitors promote the "closing" of the active site, which should be acknowledged and discussed. We thus attempted to dock the series in this "closed" IRAP following our previous protocols with GLIDE. ${ }^{30,31}$ The initial results did 
not show any conserved pose, and no inhibitor was able to make interactions with the $\mathrm{Zn}^{+2}$. This was still the case in a second round of constrained docking imposing interaction with the metal, a strategy that was useful with the "open" IRAP structure. ${ }^{30,31}$ The current exploration reinforces the idea that these series of sulfonamides cannot access the binding site for competitive inhibition considering the closed conformation of the GAMEN loop, which might be stabilized by the phosphinic derivatives due to their increased conformational flexibility, ${ }^{60}$ compared to the relatively rigid aryl sulfonamides here presented. Thus, the specificity of IRAP for the sulfonamides can, at least in part, be related to the particular configuration of its GAMEN loop typical for the open configuration of this enzyme.

\section{CONCLUSIONS}

We have extended our previously reported series of sulfonamides as inhibitors of human IRAP by synthesis of novel fluorinated analogs and performed an enzymatic and computational structural analysis of their inhibitory activity toward human IRAP. The biological data reveals several inhibitors with activity in the sub-micrometer range. Earlier computations on a limited set of sulfonamides (21, 25, and 26) predicted two possible binding modes. Here, we examined the full series of 27 compounds by molecular dynamics free energy calculations using both the linear interaction energy method and free energy perturbation simulations. The calculations on this larger set of compounds allow us to unambiguously identify the most favorable pose of the two binding poses. We foresee that this analysis will be helpful in our efforts to further improve the inhibitory capacity of IRAP inhibitors.

\section{EXPERIMENTAL SECTION}

General Information. All chemicals were purchased from Sigma-Aldrich/Apollo scientific/Acros/Fluorochem and used as received without further purification. Purification was performed on a semipreparative Gilson GX-271 RP-HPLC system, equipped with a Macherey-Nagel Nucleodur C18 column $(21 \times 125 \mathrm{~mm}, 5 \mu \mathrm{m}$ particle size $)$ and a $\mathrm{H}_{2} \mathrm{O} /$ $\mathrm{CH}_{3} \mathrm{CN} / 0.05 \% \mathrm{HCOOH}$ gradient over $15 \mathrm{~min}$. Analytical high-performance liquid chromatography mass spectrometry (HPLC-MS) was performed on a Dionex UltiMate 3000 HPLC-MS system with an ion trap mass spectrometer and detection was performed by $\mathrm{UV}(\mathrm{DAD})$ and $\mathrm{MS}\left(\mathrm{ESI}^{-}\right.$or $\left.\mathrm{ESI}^{+}\right)$using a Phenomenex Kinetex $\mathrm{C} 18$ column $(50 \times 3.0 \mathrm{~mm}$, $2.6 \mu \mathrm{m}$ particle size, $100 \AA$ pore size) and a flow rate of $1.5 \mathrm{~mL} /$ min. A gradient of $\mathrm{H}_{2} \mathrm{O} / \mathrm{CH}_{3} \mathrm{CN} / 0.05 \% \mathrm{HCOOH}$ was used.

${ }^{1} \mathrm{H}$ and ${ }^{13} \mathrm{C}$ NMR spectra were obtained on a Varian Mercury Plus spectrometer $\left({ }^{1} \mathrm{H}: 400 \mathrm{MHz},{ }^{13} \mathrm{C}: 101 \mathrm{MHz}\right)$ using $\mathrm{CDCl}_{3}, \mathrm{CD}_{3} \mathrm{OD}$, acetone- $d_{6}$, or DMSO- $d_{6}$ as solvent. HRMS were recorded on a Micromass Q-Tof2 mass spectrometer equipped with an electronspray ion source. Compounds 8-26 were prepared according to the methods previously described. ${ }^{51,52}$

General Procedure for the Synthesis of Compounds 27-34. To a solution of 3-(1H-tetrazol-5-yl)aniline (36) (0.5 mmol) in anhydrous $\mathrm{CH}_{2} \mathrm{Cl}_{2}(5 \mathrm{~mL})$ under an atmosphere of nitrogen was added appropriate sulfonyl chloride (35) (0.6 $\mathrm{mmol})$ and pyridine $(1.5 \mathrm{mmol})$. The resulting reaction mixture was stirred at room temperature overnight and then quenched with a saturated solution of $\mathrm{NH}_{4} \mathrm{Cl}(20 \mathrm{~mL})$; the $\mathrm{pH}$ was adjusted to around 4 by the addition of $1 \mathrm{M}$ aq $\mathrm{HCl}$. The aqueous phase was extracted with $\mathrm{CH}_{2} \mathrm{Cl}_{2}(3 \times 10 \mathrm{~mL})$. The combined organic phases were dried over $\mathrm{Na}_{2} \mathrm{SO}_{4}$ and evaporated under reduced pressure. The residue obtained was purified by preparative HPLC running a gradient of $\mathrm{H}_{2} \mathrm{O}$ / $\mathrm{CH}_{3} \mathrm{CN} / 0.05 \% \mathrm{HCOOH}$ to give the corresponding products.

$\mathrm{N}$-(3-(1H-Tetrazol-5-yl)phenyl)-2,3,4-trichlorobenzenesulfonamide (27). White solid, yield 58\%. ${ }^{1} \mathrm{H}$ NMR (400 MHz, methanol- $\left.d_{4}\right) \delta 8.08(\mathrm{~d}, J=8.7 \mathrm{~Hz}, 1 \mathrm{H}), 7.88$ (ddd, $J=2.2,1.7$, $0.5 \mathrm{~Hz}, 1 \mathrm{H}), 7.67$ (ddd, $J=7.7,1.7,1.1 \mathrm{~Hz}, 1 \mathrm{H}), 7.63$ (d, $J=$ $8.7 \mathrm{~Hz}, 1 \mathrm{H}$ ), 7.43 (ddd, $J=8.2,7.7,0.5 \mathrm{~Hz}, 1 \mathrm{H}), 7.32$ (ddd, $J=$ 8.2, 2.3, $1.0 \mathrm{~Hz}, 1 \mathrm{H})$. (101 MHz, methanol- $\left.d_{4}\right) \delta 156.14$, $138.65,137.79,137.24,133.69,131.54,130.28,130.11,128.33$, $125.45,122.83,122.44,118.22$. HRMS (ES) $m / z$ calcd for $[\mathrm{M}$ $+\mathrm{H}]^{+}: \mathrm{C}_{13} \mathrm{H}_{8} \mathrm{Cl}_{3} \mathrm{~N}_{5} \mathrm{O}_{2} \mathrm{~S}$ 401.9386; found 401.9390 .

$\mathrm{N}$-(3-(1H-Tetrazol-5-yl)phenyl)-3,5-bis(trifluoromethyl)benzenesulfonamide (28). White solid, yield 70\%. ${ }^{1} \mathrm{H}$ NMR $\left(400 \mathrm{MHz}\right.$, methanol- $\left.d_{4}\right) \delta 8.38(\mathrm{~m}, 1 \mathrm{H}), 8.34(\mathrm{~m}, 0.9 \mathrm{~Hz}, 1 \mathrm{H})$, $7.95(\mathrm{~m}, 1 \mathrm{H}), 7.90(\mathrm{~m}, 1 \mathrm{H}), 7.60(\mathrm{~m}, 1 \mathrm{H}), 7.41(\mathrm{~m}, 1 \mathrm{H}) .{ }^{13} \mathrm{C}$ NMR $\left(101 \mathrm{MHz}\right.$, methanol- $\left.d_{4}\right) \delta 156.22,142.16,137.84$, $132,38\left(\mathrm{q}, J^{\mathrm{C}-\mathrm{F}}=34.4 \mathrm{~Hz}\right), 130.28,127.19(\mathrm{~m}), 126.29(\mathrm{~m})$, $125.77(\mathrm{~m}), 123.84,123.61,122.49\left(\mathrm{q}, J^{\mathrm{C}-\mathrm{F}}=272.5 \mathrm{~Hz}\right)$, 119.72. HRMS (ES) $m / z$ calcd for $[\mathrm{M}+\mathrm{H}]^{+}: \mathrm{C}_{15} \mathrm{H}_{9} \mathrm{~F}_{6} \mathrm{~N}_{5} \mathrm{O}_{2} \mathrm{~S}$ 436.0303; found 436.0294

N-(3-(1H-Tetrazol-5-yl)phenyl)-2,5-bis(trifluoromethyl)benzenesulfonamide (29). White solid, yield $51 \% .{ }^{1} \mathrm{H}$ NMR $\left(400 \mathrm{MHz}\right.$, methanol- $\left.d_{4}\right) \delta 8.47(\mathrm{~m}, 1 \mathrm{H}), 8.27(\mathrm{~m}, 1 \mathrm{H}), 8.19$ (m, 1H), $7.97(\mathrm{~m}, 1 \mathrm{H}), 7.86(\mathrm{~m}, 1 \mathrm{H}), 7.58(\mathrm{~m}, 1 \mathrm{H}), 7.43(\mathrm{~m}$, $1 \mathrm{H}) .{ }^{13} \mathrm{C}$ NMR $\left(101 \mathrm{MHz}\right.$, methanol- $\left.d_{4}\right) \delta 156.25,139.65(\mathrm{~m})$, $137.69,133.80\left(\mathrm{qq}, J^{\mathrm{C}-\mathrm{F}}=34.1,0.8 \mathrm{~Hz}\right), 130.93\left(\mathrm{qq}, J^{\mathrm{C}-\mathrm{F}}=\right.$ $33.9,1.0 \mathrm{~Hz}), 130.17,129.88\left(\mathrm{qm}, J^{\mathrm{C}-\mathrm{F}}=3.7 \mathrm{~Hz}\right), 129.68(\mathrm{qm}$, $\left.J^{\mathrm{C}-\mathrm{F}}=6.4 \mathrm{~Hz}\right), 128.33\left(\mathrm{qm}, J^{\mathrm{C}-\mathrm{F}}=3.8 \mathrm{~Hz}\right), 125.66,123.43$, $123.28,122.53(\mathrm{q}, J=272.6 \mathrm{~Hz}), 122.12(\mathrm{q}, J=274.1 \mathrm{~Hz})$, 119.24. HRMS (ES) $m / z$ calcd for $[\mathrm{M}+\mathrm{H}]^{+}: \mathrm{C}_{15} \mathrm{H}_{9} \mathrm{~F}_{6} \mathrm{~N}_{5} \mathrm{O}_{2} \mathrm{~S}$ 436.0303; found 436.0308 .

N-(3-(1H-Tetrazol-5-yl)phenyl)-4-methyl-3(trifluoromethyl)benzenesulfonamide (30). White solid, yield $53 \%$ (0.33 mmol scale). ${ }^{1} \mathrm{H}$ NMR (400 MHz, methanol- $\left.d_{4}\right) \delta$ $8.11(\mathrm{~m}, 1 \mathrm{H}), 8.00(\mathrm{~m}, 1 \mathrm{H}), 7.94(\mathrm{~m}, 1 \mathrm{H}), 7.82(\mathrm{~m}, 1 \mathrm{H}), 7.61$ $(\mathrm{m}, 1 \mathrm{H}), 7.55(\mathrm{~m}, 1 \mathrm{H}), 7.39(\mathrm{~m}, 1 \mathrm{H}), 2.59(\mathrm{~m}, 3 \mathrm{H}) .{ }^{13} \mathrm{C} \mathrm{NMR}$ $\left(101 \mathrm{MHz}\right.$, methanol- $\left.d_{4}\right) \delta 156.20,142.30\left(\mathrm{q}, J^{\mathrm{C}-\mathrm{F}}=1.5 \mathrm{~Hz}\right)$, $138.52,137.65,132.85,130.21,130.07,129.12\left(\mathrm{q}, J^{\mathrm{C}-\mathrm{F}}=30.8\right.$ $\mathrm{Hz}), 125.48,124.18\left(\mathrm{q}, J^{\mathrm{C}-\mathrm{F}}=5.9 \mathrm{~Hz}\right), 123.63\left(\mathrm{q}, J^{\mathrm{C}-\mathrm{F}}=273.5\right.$ $\mathrm{Hz}), 123.25,122.97,119.11,17.99\left(\mathrm{q}, J^{\mathrm{C}-\mathrm{F}}=2.1 \mathrm{~Hz}\right)$. HRMS (ES) $m / z$ calcd for $[\mathrm{M}+\mathrm{H}]^{+}: \mathrm{C}_{15} \mathrm{H}_{12} \mathrm{~F}_{3} \mathrm{~N}_{5} \mathrm{O}_{2} \mathrm{~S}$ 382.0586; found 382.0577 .

N-(3-(1 H-Tetrazol-5-yl)phenyl)-3-methyl-4(trifluoromethyl)benzenesulfonamide (31). White solid, yield $29 \%$ (0.33 mmol scale). ${ }^{1} \mathrm{H}$ NMR (400 MHz, methanol- $\left.d_{4}\right) \delta$ $7.97(\mathrm{~m}, 1 \mathrm{H}), 7.92(\mathrm{~m}, 1 \mathrm{H}), 7.87(\mathrm{~m}, 2 \mathrm{H}), 7.82(\mathrm{~m}, 1 \mathrm{H}), 7.55$ $(\mathrm{m}, 1 \mathrm{H}), 7.40(\mathrm{~m}, 1 \mathrm{H}), 2.59(\mathrm{~m}, 3 \mathrm{H}) .{ }^{13} \mathrm{C} \mathrm{NMR}(101 \mathrm{MHz}$, methanol- $\left.d_{4}\right) \delta 156.32,142.95,138.45,138.25,132.22\left(\mathrm{q}, J^{\mathrm{C}-\mathrm{F}}\right.$ $=30.5 \mathrm{~Hz}), 130.05,130.00,126.42\left(\mathrm{q}, J^{\mathrm{C}-\mathrm{F}}=5.7 \mathrm{~Hz}\right), 125.61$, $124.59,123.72\left(\mathrm{q}, J^{\mathrm{C}-\mathrm{F}}=273.5 \mathrm{~Hz}\right), 123.09,122.95,119.05$, $17.97\left(\mathrm{q}, J^{\mathrm{C}-\mathrm{F}}=2.2 \mathrm{~Hz}\right)$. HRMS (ES) $\mathrm{m} / z$ calcd for $[\mathrm{M}+\mathrm{H}]^{+}$: $\mathrm{C}_{15} \mathrm{H}_{12} \mathrm{~F}_{3} \mathrm{~N}_{5} \mathrm{O}_{2} \mathrm{~S}$ 382.0586; found 382.0581.

N-(3-(1 H-Tetrazol-5-yl)phenyl)-3-fluoro-4(trifluoromethyl)benzenesulfonamide (32). White solid, yield $22 \%$ (0.33 mmol scale). ${ }^{1} \mathrm{H}$ NMR (400 MHz, methanol- $\left.d_{4}\right) \delta$ 7.89-7.82 (m, 2H), 7.80-7.72 (m, 3H), 7.47 (m, 1H), 7.30 (ddd, $J=8.1,2.3,1.0 \mathrm{~Hz}, 1 \mathrm{H}) .{ }^{13} \mathrm{C}$ NMR $(101 \mathrm{MHz}$, methanol$\left.d_{4}\right) \delta 159.30\left(\mathrm{dq}, J^{\mathrm{C}-\mathrm{F}}=260.4,2.0 \mathrm{~Hz}\right), 156.32,145.71(\mathrm{dq}$, $\left.J^{\mathrm{C}-\mathrm{F}}=6.7,1.1 \mathrm{~Hz}\right), 138.02,130.17,128.32\left(\mathrm{dq}, J^{\mathrm{C}-\mathrm{F}}=4.7,1.1\right.$ $\mathrm{Hz}), 125.76,123.33\left(\mathrm{~d}, J^{\mathrm{C}-\mathrm{F}}=1.6 \mathrm{~Hz}\right), 123.04\left(\mathrm{~d}, J^{\mathrm{C}-\mathrm{F}}=4.7\right.$ 
$\mathrm{Hz}), 122.95\left(\mathrm{dq}, J^{\mathrm{C}-\mathrm{F}}=272.34,1.1 \mathrm{~Hz}\right), 122.58\left(\mathrm{dq}, J^{\mathrm{C}-\mathrm{F}}=\right.$ $33.5,12.6 \mathrm{~Hz}$ ), 119.30, 115.65, 115.41. HRMS (ES) $\mathrm{m} / z$ calcd for $[\mathrm{M}+\mathrm{H}]^{+}: \mathrm{C}_{14} \mathrm{H}_{9} \mathrm{~F}_{4} \mathrm{~N}_{5} \mathrm{O}_{2} \mathrm{~S}$ 386.0335; found 386.0345 .

$\mathrm{N}$-(3-(1 H-Tetrazol-5-yl)phenyl) - 2 - fluoro-5(trifluoromethyl)benzenesulfonamide (33). White solid, yield $55 \% .{ }^{1} \mathrm{H}$ NMR (400 MHz, methanol- $\left.d_{4}\right) \delta 8.15$ (dd, $J=6.2,2.3$ $\mathrm{Hz}, 1 \mathrm{H}), 7.94(\mathrm{~m}, 1 \mathrm{H}), 7.87(\mathrm{~m}, 1 \mathrm{H}), 7.72$ (ddd, $J=7.7,1.7$, $1.1 \mathrm{~Hz}, 1 \mathrm{H}), 7.51-7.43(\mathrm{~m}, 2 \mathrm{H}), 7.35(\mathrm{ddd}, J=8.2,2.2,1.1 \mathrm{~Hz}$, $1 \mathrm{H}) .\left(101 \mathrm{MHz}\right.$, methanol- $\left.d_{4}\right) \delta 160.65\left(\mathrm{dm}, J^{\mathrm{C}-\mathrm{F}}=262.1 \mathrm{~Hz}\right)$, $156.32,137.80,132.64\left(\mathrm{dq}, J^{\mathrm{C}-\mathrm{F}}=10.0,3.7 \mathrm{~Hz}\right), 130.08,128.30$ $\left(\mathrm{d}, J^{\mathrm{C}-\mathrm{F}}=15.7 \mathrm{~Hz}\right), 127.95\left(\mathrm{dq}, J^{\mathrm{C}-\mathrm{F}}=3.9,1.1 \mathrm{~Hz}\right), 126.72$ $\left(\mathrm{dq}, J^{\mathrm{C}-\mathrm{F}}=34.1,3.9 \mathrm{~Hz}\right), 125.68,123.04\left(\mathrm{~d}, J^{\mathrm{C}-\mathrm{F}}=19.9 \mathrm{~Hz}\right)$, $122.96\left(\mathrm{q}, J^{\mathrm{C}-\mathrm{F}}=271.7 \mathrm{~Hz}\right), 118.88,118.33,118.10$. HRMS (ES) $m / z$ calcd for $[\mathrm{M}+\mathrm{H}]^{+}: \mathrm{C}_{14} \mathrm{H}_{9} \mathrm{~F}_{4} \mathrm{~N}_{5} \mathrm{O}_{2} \mathrm{~S}$ 386.0335; found 386.0331 .

$\mathrm{N}$-(3-(1H-Tetrazol-5-yl)phenyl)-3,4-difluorobenzenesulfonamide (34). White solid, yield 53\%. ${ }^{1} \mathrm{H}$ NMR (400 $\mathrm{MHz}$, methanol- $\left.d_{4}\right) \delta 7.73(\mathrm{~m}, 1 \mathrm{H}), 7.68-7.61(\mathrm{~m}, 2 \mathrm{H}), 7.55(\mathrm{~m}$, $1 \mathrm{H}), 7.38-7.27$ (m, 2H), 7.19 (ddd, $J=8.1,2.2,1.0 \mathrm{~Hz}, 1 \mathrm{H})$. $\left(101 \mathrm{MHz}\right.$, methanol- $\left.d_{4}\right) \delta 156.64,152.93\left(\mathrm{dd}, J^{\mathrm{C}-\mathrm{F}}=255.3\right.$, $12.3 \mathrm{~Hz}), 149.83\left(\mathrm{dd}, J^{\mathrm{C}-\mathrm{F}}=252.6,13.5 \mathrm{~Hz}\right), 138.33,136.54$, $130.02,126.04,124.53\left(\mathrm{dd}, J^{\mathrm{C}-\mathrm{F}}=7.8,4.0 \mathrm{~Hz}\right), 123.05,123.03$, $119.11,117.94\left(\mathrm{~d}, J^{\mathrm{C}-\mathrm{F}}=18.8 \mathrm{~Hz}\right), 116.55\left(\mathrm{dd}, J^{\mathrm{C}-\mathrm{F}}=20.1,1.4\right.$ $\mathrm{Hz}$ ). HRMS (ES) $m / z$ calcd for $[\mathrm{M}+\mathrm{H}]^{+}: \mathrm{C}_{13} \mathrm{H}_{9} \mathrm{~F}_{2} \mathrm{~N}_{5} \mathrm{O}_{2} \mathrm{~S}$ 336.0367; found 336.0369.

Enzyme Assay. The efficacy of the candidate compounds to inhibit IRAP enzymatic activity was analyzed using solubilized, crude membranes isolated from HEK293 cells (ATCC, Manassas, VA) transfected with pCI-IRAP. Membranes from vector-only transfected cells were used as a negative control. IRAP enzymatic activity was determined by the hydrolysis of the synthetic substrate L-leucine-4-methyl-7coumarinylamide (Sigma-Aldrich, St Louis, MO) and monitored by the release of a fluorogenic product at excitation and emission wavelengths of 380 and $430 \mathrm{~nm}$, respectively. Assays were performed in 96-well plates; each well contained $1 \mu \mathrm{g}$ of solubilized membrane protein and $25 \mu \mathrm{M}$ substrate in a final volume of $100 \mu \mathrm{L}$ in $50 \mathrm{mM}$ Tris- $\mathrm{HCl}$ buffer $(\mathrm{pH} 7.4)$. Reactions were performed at $37^{\circ} \mathrm{C}$ for 30 min using a Wallac Victor3 V Multilabel counter (PerkinElmer, Waltham, MA). $\mathrm{IC}_{50}$ values for each of the inhibitors were determined over a range of concentrations $(0.01-100 \mu \mathrm{M})$ and were calculated from three independent experiments, reporting the mean \pm SEM.

Preparation of the IRAP Structure and Ligand Docking. The crystal structure of human IRAP was retrieved from the protein data bank (PDB code 4PJ6), ${ }^{56}$ and chain A of the crystal dimer was retained and prepared for molecular dynamics (MD) simulations. The preparation of the structure (i.e., addition of hydrogens, rotamer assignment of Asn and His) was performed with Maestro version 9.2. (Schrödinger, LLC; NY). The series of sulfonamides was built in a reliable three-dimensional conformation with the same software, and each compound was docked by structural alignment ("flexible ligand superposition" protocol in Schrödinger) in each of the two binding modes (pose $A$ and pose $B$ ) previously determined for compound $26^{30,31}$ The last complex was superimposed to the crystal structures of the homologous enzymes APN and LTA4H (PDB codes $4 \mathrm{FYQ}^{58}$ and $2 \mathrm{VJ} 8,{ }^{59}$ respectively) using the $\mathrm{PyMol}^{61}$ graphical interface, to analyze the structural reasons for selectivity.

Molecular Dynamics (MD) Simulations. MD simulations were performed under spherical boundary conditions using program $\mathrm{Q}^{62}$ allowing an efficient sampling of the free energies of many ligands at a low computational cost, while attaining reliable statistics. ${ }^{63,64}$ The all-atom optimized potentials for liquid simulations force field for proteins was used, ${ }^{65}$ in combination with compatible parameters for $\mathrm{Zn}^{2+}$ ion and automatic parameterization of the ligands, performed with Macromodel version 10.6 (Schrödinger LLC). A simulation sphere of $25 \AA$ radius centered on the equivalent position of the $\mathrm{C} \alpha$ atom of His4 in Ang IV was built as previously described. ${ }^{30,31}$ The sphere was solvated with TIP3P water molecules ${ }^{66}$ and subjected to polarization and radial constraints according to the surface-constrained all-atom solvent model ${ }^{62,67}$ to mimic the properties of bulk water at the sphere surface. Protein atoms outside the simulation sphere were restrained to their initial positions and only interacted with the system through bonds, angles, and torsions. Excluding His, all other titratable residues within $20 \AA$ of the $\mathrm{Zn}^{2+}$ ion were treated in their charged form. In addition, the residues Lys520, Lys726, Glu767, Asp773, Arg817, Glu818, Arg820, Glu825, Arg858, Glu887, Lys890, Lys892, Glu895, Arg933, and Glu1002, in the 20-25 A layer of the sphere, were also treated as ionized because they were forming salt bridges. With this setup, the simulation sphere was overall neutral, thus avoiding the consideration of additional Born terms in the calculation of free energies of charged ligands as compared to that of the bulk solvent. Nonbonded interactions were calculated explicitly up to a $10 \AA$ cutoff, except for the ligand atoms for which no cutoff was used. Beyond the direct cutoff, long-range electrostatics were treated with the local reaction field multipole expansion method. ${ }^{6}$ During a 175 ps equilibration stage, the system was slowly heated to the target temperature of $310 \mathrm{~K}$ while initial positional restrains on all solute heavy atoms were gradually released. The subsequent data collection phase consisted of 10 replica MD simulations of $2 \mathrm{~ns}$ each, with randomized initial velocities, accounting for a total of $20 \mathrm{~ns}$ sampling trajectories where the ligand-surrounding energies were collected for binding affinity calculations. A time step of 1 fs was used, and no positional restraints were applied. Solvent bonds and angles were constrained using the SHAKE algorithm. ${ }^{69}$ Nonbonded pair lists were updated every 25 steps, and the ligand-surrounding interaction energies were sampled every 50 steps. To estimate free energies of binding, ligand-surrounding energies were also sampled in parallel MD simulations of the reference state, that, solvated in water, using the same conditions as for the bound state.

Linear Interaction Energy Binding Affinity Calculations. Binding free energies of every compound were calculated using the linear interaction energy (LIE) method as 54,55

$$
\Delta G_{\mathrm{bind}}^{\mathrm{calc}}=\alpha \Delta\left\langle U_{1-\mathrm{s}}^{\mathrm{vdW}}\right\rangle+\beta \Delta\left\langle U_{1-\mathrm{s}}^{\mathrm{el}}\right\rangle+\gamma
$$

where $\Delta\left\langle U_{\mathrm{l}-\mathrm{s}}^{\mathrm{vdW}}\right\rangle$ and $\Delta\left\langle U_{\mathrm{l}-\mathrm{s}}^{\mathrm{el}}\right\rangle$ are, respectively, the differences in the average nonpolar and polar ligand-surrounding interaction energies in the two states, that is, free and bound ligands. The coefficients $\alpha$ and $\beta$ are scaling parameters ${ }^{55,70,71}$ for the nonpolar and polar terms, respectively. In the standard LIE model, $\alpha$ has a value of 0.18 , whereas $\beta$ depends on the chemical nature of the ligand. The IRAP active site has a divalent $\mathrm{Zn}^{2+}$ ion together with a cluster of carboxylates, causing very large electrostatic interaction energies with the ligands. Because these interaction energies, particularly those involving the $\mathrm{Zn}^{2+}$ ion, will be very sensitive to the force field parameters, we follow a protocol used earlier for binding sites 
containing ions ${ }^{57}$ and treated as a free parameter. An electrostatic correction term ${ }^{62}$ was added to account for the long-range interactions of the charged sulfonamides with the neglected charges of the neutralized titratable residues. This term was calculated as $\Delta G_{\text {corr }}^{\mathrm{el}}=0.64 \mathrm{kcal} / \mathrm{mol}$ following the relationship

$$
\Delta G_{\text {corr }}^{\mathrm{el}}=332 \sum_{p} \sum_{l} \frac{q_{p} q_{l}}{\varepsilon r_{p l}}
$$

where $q_{p}$ is the formal charge of the neglected ionic group, whereas $q_{l}$ is the partial charge of the ligand atom. The effective dielectric constant $\varepsilon$ was set to 80 . The last term $\gamma$ is a proteindependent constant that does not affect the relative binding free energies ${ }^{70}$ but is used to offset the resulting calculated energies to the experimental values. The reported nonbonded energies correspond to average values over all 10 replicates, and the corresponding errors are calculated as the standard error of the mean (SEM).

Experimental binding free energies $\left(\Delta G_{\text {bind }}^{\text {exp }}\right)$ were extracted from $\mathrm{IC}_{50}$ values as

$$
\Delta G_{\text {bind }}^{\text {exp }}=R T \ln K_{\mathrm{d}}=R T \ln \mathrm{IC}_{50}+c
$$

where $c$ is an assay-specific constant, which depends on the substrate concentration and the enzymatic $K_{\mathrm{m}}$ value. ${ }^{72}$ This constant value does not affect the relative free energies and is implicitly included in the optimized value of $\gamma$ in eq 1 .

Free Energy Perturbation. The relative binding free energy between selected pairs of ligands, $\mathrm{LIG}_{\mathrm{A}}$ and $\mathrm{LIG}_{\mathrm{B}}$, was calculated using the free energy perturbation method. In this method, $\mathrm{LIG}_{\mathrm{A}}$ is transformed into $\mathrm{LIG}_{\mathrm{B}}$ in parallel $\mathrm{MD}$ simulations in both the bound and the reference (watersolvated) state, and the relative binding free energy is estimated via a standard thermodynamic cycle, where the free energy of binding is calculated as the difference in the free energy resulting in transforming each ligand pair, A, B, in both the bound and the solvated reference state as

$$
\Delta G_{\text {bind }}^{\mathrm{B}}-\Delta G_{\text {bind }}^{\mathrm{A}}=\Delta \Delta G_{\text {bind }}=\Delta G_{\text {bound }}^{\mathrm{A} \rightarrow \mathrm{B}}-\Delta G_{\text {free }}^{\mathrm{A} \rightarrow \mathrm{B}}
$$

The free energy difference associated with the transformation of ligands A to B was calculated using Zwanzig's exponential formula $^{73}$

$$
\Delta G=G_{\mathrm{B}}-G_{\mathrm{A}}=-\beta^{-1} \sum_{m=1}^{n-1} \ln \left\langle\exp \left(-\beta^{-1}\left(U_{m+1}-U_{m}\right)\right)\right\rangle_{\mathrm{A}}
$$

where $U_{m}$ denotes the effective potential energy function of a particular FEP window and $n$ is the number of intermediate states. $U_{m}$ is constructed as a linear combination of the initial (A) and final (B) potentials of the subperturbation

$$
U_{m}=\left(1-\lambda_{m}\right) U_{\mathrm{A}}+\lambda_{m} U_{\mathrm{B}}
$$

where the coupling parameter $\lambda_{m}$ is stepwise incremented from 0 to 1 , in our case divided into $51 \lambda$-windows, where every window is sampled for 30 ps.

\section{ASSOCIATED CONTENT}

\section{S Supporting Information}

The Supporting Information is available free of charge on the ACS Publications website at DOI: 10.1021/acsomega.8b00595.

Comparison of $\mathrm{IC}_{50}$ values of the sulfonamide series obtained in CHO and HEK293 cells; decomposition of the electrostatic and nonelectrostatic components of the free energy of binding for the LIE analyses; FEP transformations performed in pose A (PDF)

Structures of compounds 8-34 (CSV)

Crystallographic data (ZIP)

\section{AUTHOR INFORMATION}

\section{Corresponding Authors}

*E-mail: siew.chai@monash.edu. Phone: +61 3990 52515. Fax: +61399052547 (S.Y.C.).

*E-mail: hugo.gutierrez@icm.uu.se. Phone: +46 184715056. Fax: +4618 536971 (H.G.-d.-T.).

ORCID 우

Mats Larhed: 0000-0001-6258-0635

Johan Åqvist: 0000-0003-2091-0610

Hugo Gutiérrez-de-Terán: 0000-0003-0459-3491

Notes

The authors declare no competing financial interest.

\section{ACKNOWLEDGMENTS}

We thank Dr Richard Svensson at the Chemical Biology Consortium Sweden, Science for Life Laboratory, UDOPP, at the Department of Pharmacy, Uppsala University, for providing data on the stability of compounds in microsomes. The simulations were performed on resources provided by Swedish National Infrastructure for Computing (SNIC) at HPC2N and C3SE. Support from the Swedish Research Council (VR), The Kjell and Märta Beijer Foundation, the King Gustaf V and Queen Victoria Freemason Foundation, and The Swedish Brain Foundation are gratefully acknowledged.

\section{REFERENCES}

(1) Albiston, A. L.; Pederson, E. S.; Burns, P.; Purcell, B.; Wright, J. W.; Harding, J. W.; Mendelsohn, F. A.; Weisinger, R. S.; Chai, S. Y. Attenuation of Scopolamine-Induced Learning Deficits by LVVHemorphin-7 in Rats in the Passive Avoidance and Water Maze Paradigms. Behav. Brain Res. 2004, 154, 239-243.

(2) Braszko, J. J.; Kupryszewski, G.; Witczuk, B.; Wiśniewski, K. Angiotensin Ii-(3-8)-Hexapeptide Affects Motor Activity, Performance of Passive Avoidance and a Conditioned Avoidance Response in Rats. Neuroscience 1988, 27, 777-783.

(3) Gard, P. R. Cognitive-Enhancing Effects of Angiotensin IV. BMC Neurosci. 2008, 9, No. S15.

(4) Lee, J.; Albiston, A. L.; Allen, A. M.; Mendelsohn, F. A. O.; Ping, S. E.; Barrett, G. L.; Murphy, M.; Morris, M. J.; McDowall, S. G.; Chai, S. Y. Effect of I.C.V. Injection of AT4 Receptor Ligands, NLE1Angiotensin IV and LVV-Hemorphin 7, on Spatial Learning in Rats. Neuroscience 2004, 124, 341-349.

(5) Pederson, E. S.; Harding, J. W.; Wright, J. W. Attenuation of Scopolamine-Induced Spatial Learning Impairments by an Angiotensin IV Analog. Regul. Pept. 1998, 74, 97-103.

(6) Pederson, E. S.; Krishnan, R.; Harding, J. W.; Wright, J. W. A Role for the Angiotensin AT4 Receptor Subtype in Overcoming Scopolamine-Induced Spatial Memory Deficits. Regul. Pept. 2001, 102, $147-156$

(7) Wright, J. W.; Miller-Wing, A. V.; Shaffer, M. J.; Higginson, C.; Wright, D. E.; Hanesworth, J. M.; Harding, J. W. Angiotensin II(3-8) (ANG IV) Hippocampal Binding: Potential Role in the Facilitation of Memory. Brain Res. Bull. 1993, 32, 497-502.

(8) Wright, J. W.; Stubley, L.; Pederson, E. S.; Kramár, E. A.; Hanesworth, J. M.; Harding, J. W. Contributions of the Brain Angiotensin IV-AT4 Receptor Subtype System to Spatial Learning. J. Neurosci. 1999, 19, 3952-3961. 
(9) Hallberg, M. Neuropeptides: Metabolism to Bioactive Fragments and the Pharmacology of Their Receptors. Med. Res. Rev. 2015, 35, 464-519.

(10) Nyberg, F.; Hallberg, M. Peptide Conversion: A Potential Pathway Modulating G-Protein Signaling. Curr. Drug Targets 2007, 8, 147-154.

(11) Albiston, A. L.; McDowall, S. G.; Matsacos, D.; Sim, P.; Clune, E.; Mustafa, T.; Lee, J.; Mendelsohn, F. A. O.; Simpson, R. J.; Connolly, L. M.; et al. Evidence That the Angiotensin IV (AT4) Receptor Is the Enzyme Insulin-Regulated Aminopeptidase. J. Biol. Chem. 2001, 276, 48623-48626.

(12) Lee, J.; Mustafa, T.; McDowall, S. G.; Mendelsohn, F. A. O.; Brennan, M.; Lew, R. A.; Albiston, A. L.; Chai, S. Y. Structure-Activity Study of LVV-Hemorphin-7: Angiotensin AT4 Receptor Ligand and Inhibitor of Insulin-Regulated Aminopeptidase. J. Pharmacol. Exp. Ther. 2003, 305, 205-211.

(13) Lew, R. A.; Mustafa, T.; Ye, S.; McDowall, S. G.; Chai, S. Y.; Albiston, A. L. Angiotensin AT4 Ligands Are Potent, Competitive Inhibitors of Insulin Regulated Aminopeptidase (IRAP). J. Neurochem. 2003, 86, 344-350.

(14) Saveanu, L.; Carroll, O.; Weimershaus, M.; Guermonprez, P.; Firat, E.; Lindo, V.; Greer, F.; Davoust, J.; Kratzer, R.; Keller, S. R.; et al. IRAP Identifies an Endosomal Compartment Required for MHC Class I Cross-Presentation. Science 2009, 325, 213-217.

(15) Segura, E.; Albiston, A. L.; Wicks, I. P.; Chai, S. Y.; Villadangos, J. A. Different Cross-Presentation Pathways in Steady-State and Inflammatory Dendritic Cells. Proc. Natl. Acad. Sci. U.S.A. 2009, 106, 20377-20381.

(16) Albiston, A. L.; Peck, G. R.; Yeatman, H. R.; Fernando, R.; Ye, S.; Chai, S. Y. Therapeutic Targeting of Insulin-Regulated Aminopeptidase: Heads and Tails? Pharmacol. Ther. 2007, 116, 417-427.

(17) Evnouchidou, I.; Papakyriakou, A.; Stratikos, E. A New Role for $\mathrm{Zn}$ (II) Aminopeptidases: Antigenic Peptide Generation and Destruction. Curr. Pharm. Des. 2009, 15, 3656.

(18) Stratikos, E. Regulating Adaptive Immune Responses Using Small Molecule Modulators of Aminopeptidases That Process Antigenic Peptides. Curr. Opin. Chem. Biol. 2014, 23, 1-7.

(19) Benoist, C. C.; Kawas, L. H.; Zhu, M.; Tyson, K. A.; Stillmaker, L.; Appleyard, S. M.; Wright, J. W.; Wayman, G. A.; Harding, J. W. The Procognitive and Synaptogenic Effects of Angiotensin IVDerived Peptides Are Dependent on Activation of the Hepatocyte Growth Factor/C-Met System. J. Pharmacol. Exp. Ther. 2014, 351, 390-402.

(20) Kawas, L. H.; McCoy, A. T.; Yamamoto, B. J.; Wright, J. W.; Harding, J. W. Development of Angiotensin IV Analogs as Hepatocyte Growth Factor/Met Modifiers. J. Pharmacol. Exp. Ther. 2012, 340, 539-548.

(21) Vanderheyden, P. M. L. From Angiotensin IV Binding Site to AT4 Receptor. Mol. Cell. Endocrinol. 2009, 302, 159-166.

(22) Albiston, A. L.; Mustafa, T.; McDowall, S. G.; Mendelsohn, F. A. O.; Lee, J.; Chai, S. Y. AT4 Receptor Is Insulin-Regulated Membrane Aminopeptidase: Potential Mechanisms of Memory Enhancement. Trends Endocrinol. Metab. 2003, 14, 72-77.

(23) Chai, S. Y.; Fernando, R.; Peck, G.; Ye, S.-Y.; Mendelsohn, F. A. O.; Jenkins, T. A.; Albiston, A. L. What's New in the ReninAngiotensin System? The Angiotensin IV/AT4 Receptor. Cell. Mol. Life Sci. 2004, 61, 2728-2737.

(24) Ragozzino, M. E.; Unick, K. E.; Gold, P. E. Hippocampal Acetylcholine Release during Memory Testing in Rats: Augmentation by Glucose. Proc. Natl. Acad. Sci. U.S.A. 1996, 93, 4693-4698.

(25) Albiston, A. L.; Cacador, M.; Sinnayah, P.; Burns, P.; Chai, S. Y. Insulin-Regulated Aminopeptidase Inhibitors Do Not Alter Glucose Handling in Normal and Diabetic Rats. J. Mol. Endocrinol. 2017, 58, 193-198.

(26) Stragier, B.; Bundel, D. D.; Sarre, S.; Smolders, I.; Vauquelin, G.; Dupont, A.; Michotte, Y.; Vanderheyden, P. Involvement of InsulinRegulated Aminopeptidase in the Effects of the Renin-angiotensin Fragment Angiotensin IV: A Review. Heart Failure Rev. 2008, 13, 321-337.
(27) Chai, S. Y.; Yeatman, H. R.; Parker, M. W.; Ascher, D. B.; Thompson, P. E.; Mulvey, H. T.; Albiston, A. L. Development of Cognitive Enhancers Based on Inhibition of Insulin-Regulated Aminopeptidase. BMC Neurosci. 2008, 9, No. S14.

(28) Hallberg, M. Targeting the Insulin-Regulated Aminopeptidase/ AT4 Receptor for Cognitive Disorders. Drug News Perspect. 2009, 22, 133-139.

(29) Wolfe, M. S. Therapeutic Strategies for Alzheimer's Disease. Nat. Rev. Drug Discovery 2002, 1, 859-866.

(30) Diwakarla, S.; Nylander, E.; Gronbladh, A.; Vanga, S. R.; Khan, Y. S.; Gutierrez-de-Teran, H.; Ng, L.; Pham, V.; Savmarker, J.; Lundback, T.; et al. Binding to and Inhibition of Insulin-Regulated Aminopeptidase (IRAP) by Macrocyclic Disulfides Enhances Spine Density. Mol. Pharmacol. 2016, 89, 413-424.

(31) Diwakarla, S.; Nylander, E.; Grönbladh, A.; Vanga, S. R.; Khan, Y. S.; Gutiérrez-de-Terán, H.; Sävmarker, J.; Ng, L.; Pham, V.; Lundbäck, T.; et al. Aryl Sulfonamide Inhibitors of Insulin-Regulated Aminopeptidase Enhance Spine Density in Primary Hippocampal Neuron Cultures. ACS Chem. Neurosci. 2016, 7, 1383-1392.

(32) Kobori, T.; Goda, K.; Sugimoto, K.; Ota, T.; Tomisawa, K. Peptide Derivatives and Angiotensin Iv Receptor Agonist. WO1997003093 A1, January 30, 1997.

(33) Kobori, T.; Goda, K.; Sugimoto, K.; Ota, T.; Tomisawa, K. Amino Compounds and Angiotensin IV Receptor Agonists. WO1998005624 A1, February 12, 1998.

(34) Lukaszuk, A.; Demaegdt, H.; Szemenyei, E.; Tóth, G.; Tymecka, D.; Misicka, A.; Karoyan, P.; Vanderheyden, P.; Vauquelin, G.; Tourwé, D. $\beta$-Homo-Amino Acid Scan of Angiotensin IV. J. Med. Chem. 2008, 51, 2291-2296.

(35) Lukaszuk, A.; Demaegdt, H.; Feytens, D.; Vanderheyden, P.; Vauquelin, G.; Tourwé, D. The Replacement of His(4) in Angiotensin IV by Conformationally Constrained Residues Provides Highly Potent and Selective Analogues. J. Med. Chem. 2009, 52, 5612-5618.

(36) Andersson, H.; Hallberg, M. Discovery of Inhibitors of InsulinRegulated Aminopeptidase as Cognitive Enhancers. Int. J. Hypertens. 2012, 2012, No. 789671

(37) Andersson, H.; Demaegdt, H.; Vauquelin, G.; Lindeberg, G.; Karlén, A.; Hallberg, M. Ligands to the (IRAP)/AT4 Receptor Encompassing a 4-Hydroxydiphenylmethane Scaffold Replacing Tyr2. Bioorg. Med. Chem. 2008, 16, 6924-6935.

(38) Andersson, H.; Demaegdt, H.; Vauquelin, G.; Lindeberg, G.; Karlén, A.; Hallberg, M.; Erdélyi, M.; Hallberg, A. Disulfide Cyclized Tripeptide Analogues of Angiotensin IV as Potent and Selective Inhibitors of Insulin-Regulated Aminopeptidase (IRAP). J. Med. Chem. 2010, 53, 8059-8071.

(39) Andersson, H.; Demaegdt, H.; Johnsson, A.; Vauquelin, G.; Lindeberg, G.; Hallberg, M.; Erdélyi, M.; Karlén, A.; Hallberg, A. Potent Macrocyclic Inhibitors of Insulin-Regulated Aminopeptidase (IRAP) by Olefin Ring-Closing Metathesis. J. Med. Chem. 2011, 54, 3779-3792.

(40) Axén, A.; Lindeberg, G.; Demaegdt, H.; Vauquelin, G.; Karlén, A.; Hallberg, M. Cyclic Insulin-Regulated Aminopeptidase (IRAP)/ AT4 Receptor Ligands. J. Pept. Sci. 2006, 12, 705-713.

(41) Axén, A.; Andersson, H.; Lindeberg, G.; Rönnholm, H.; Kortesmaa, J.; Demaegdt, H.; Vauquelin, G.; Karlén, A.; Hallberg, M. Small Potent Ligands to the Insulin-Regulated Aminopeptidase (IRAP)/AT4 Receptor. J. Pept. Sci. 2007, 13, 434-444.

(42) Benoist, C. C.; Wright, J. W.; Zhu, M.; Appleyard, S. M.; Wayman, G. A.; Harding, J. W. Facilitation of Hippocampal Synaptogenesis and Spatial Memory by C-Terminal Truncated Nle1Angiotensin IV Analogs. J. Pharmacol. Exp. Ther. 2011, 339, 35-44.

(43) McCoy, A. T.; Benoist, C. C.; Wright, J. W.; Kawas, L. H.; BuleGhogare, J. M.; Zhu, M.; Appleyard, S. M.; Wayman, G. A.; Harding, J. W. Evaluation of Metabolically Stabilized Angiotensin IV Analogs as Procognitive/Antidementia Agents. J. Pharmacol. Exp. Ther. 2013, 344, $141-154$.

(44) Mountford, S. J.; Albiston, A. L.; Charman, W. N.; Ng, L.; Holien, J. K.; Parker, M. W.; Nicolazzo, J. A.; Thompson, P. E.; Chai, S. Y. Synthesis, Structure-Activity Relationships and Brain Uptake of a 
Novel Series of Benzopyran Inhibitors of Insulin-Regulated Aminopeptidase. J. Med. Chem. 2014, 57, 1368-1377.

(45) Albiston, A. L.; Morton, C. J.; Ng, H. L.; Pham, V.; Yeatman, H. R.; Ye, S.; Fernando, R. N.; Bundel, D. D.; Ascher, D. B.; Mendelsohn, F. A. O.; et al. Identification and Characterization of a New Cognitive Enhancer Based on Inhibition of Insulin-Regulated Aminopeptidase. FASEB J. 2008, 22, 4209-4217.

(46) Albiston, A. L.; Diwakarla, S.; Fernando, R. N.; Mountford, S. J.; Yeatman, H. R.; Morgan, B.; Pham, V.; Holien, J. K.; Parker, M. W.; Thompson, P. E.; et al. Identification and Development of Specific Inhibitors for Insulin-Regulated Aminopeptidase as a New Class of Cognitive Enhancers. Br. J. Pharmacol. 2011, 164, 37-47.

(47) Papakyriakou, A.; Zervoudi, E.; Tsoukalidou, S.; Mauvais, F.-X.; Sfyroera, G.; Mastellos, D. C.; van Endert, P.; Theodorakis, E. A.; Vourloumis, D.; Stratikos, E. 3,4-Diaminobenzoic Acid Derivatives as Inhibitors of the Oxytocinase Subfamily of M1 Aminopeptidases with Immune-Regulating Properties. J. Med. Chem. 2015, 58, 1524-1543.

(48) Kokkala, P.; Mpakali, A.; Mauvais, F.-X.; Papakyriakou, A.; Daskalaki, I.; Petropoulou, I.; Kavvalou, S.; Papathanasopoulou, M.; Agrotis, S.; Fonsou, T.-M.; et al. Optimization and Structure-Activity Relationships of Phosphinic Pseudotripeptide Inhibitors of Aminopeptidases That Generate Antigenic Peptides. J. Med. Chem. 2016, 59, 9107-9123.

(49) Zervoudi, E.; Saridakis, E.; Birtley, J. R.; Seregin, S. S.; Reeves, E.; Kokkala, P.; Aldhamen, Y. A.; Amalfitano, A.; Mavridis, I. M.; James, E.; et al. Rationally Designed Inhibitor Targeting AntigenTrimming Aminopeptidases Enhances Antigen Presentation and Cytotoxic T-Cell Responses. Proc. Natl. Acad. Sci. U.S.A. 2013, 110, 19890-19895.

(50) Engen, K.; Rosenström, U.; Axelsson, H.; Konda, V.; Dahllund, L.; Otrocka, M.; Sigmundsson, K.; Nikolaou, A.; Vauquelin, G.; Hallberg, M.; et al. Identification of Drug-Like Inhibitors of InsulinRegulated Aminopeptidase Through Small-Molecule Screening. Assay Drug Dev. Technol. 2016, 14, 180-193.

(51) Borhade, S. R.; Rosenström, U.; Sävmarker, J.; Lundbäck, T.; Jenmalm-Jensen, A.; Sigmundsson, K.; Axelsson, H.; Svensson, F.; Konda, V.; Sköld, C.; et al. Inhibition of Insulin-Regulated Aminopeptidase (IRAP) by Arylsulfonamides. ChemistryOpen 2014, 3, 256263.

(52) Byström, S.; Färnegårdh, K.; Hedgecock, C.; Homan, E.; Jönsson, M.; Lundbäck, T.; Martinsson, J.; Sari, M. Sulfonamide Compounds. WO2012035171 A3, June 21, 2012.

(53) Caraballo, R.; Larsson, M.; Nilsson, S. K.; Ericsson, M.; Qian, W.; Nguyen Tran, N. P.; Kindahl, T.; Svensson, R.; Saar, V.; Artursson, P.; et al. Structure-activity Relationships for Lipoprotein Lipase Agonists That Lower Plasma Triglycerides in Vivo. Eur. J. Med. Chem. 2015, 103, 191-209.

(54) Aqvist, J.; Medina, C.; Samuelsson, J. E. A New Method for Predicting Binding Affinity in Computer-Aided Drug Design. Protein Eng., Des. Sel. 1994, 7, 385-391.

(55) Hansson, T.; Marelius, J.; Aqvist, J. Ligand Binding Affinity Prediction by Linear Interaction Energy Methods. J. Comput.-Aided Mol. Des. 1998, 12, 27-35.

(56) Hermans, S. J.; Ascher, D. B.; Hancock, N. C.; Holien, J. K.; Michell, B. J.; Chai, S. Y.; Morton, C. J.; Parker, M. W. Crystal Structure of Human Insulin-Regulated Aminopeptidase with Specificity for Cyclic Peptides. Protein Sci. 2015, 24, 190-199.

(57) Mishra, S. K.; Sund, J.; Åqvist, J.; Koča, J. Computational Prediction of Monosaccharide Binding Free Energies to Lectins with Linear Interaction Energy Models. J. Comput. Chem. 2012, 33, 23402350.

(58) Wong, A. H. M.; Zhou, D.; Rini, J. M. The X-Ray Crystal Structure of Human Aminopeptidase N Reveals a Novel Dimer and the Basis for Peptide Processing. J. Biol. Chem. 2012, 287, 3680436813.

(59) Thunnissen, M. M. G. M.; Andersson, B.; Samuelsson, B.; Wong, C.-H.; Haeggström, J. Z. Crystal Structures of Leukotriene A4 Hydrolase in Complex with Captopril and Two Competitive TightBinding Inhibitors. FASEB J. 2002, 16, 1648-1650.
(60) Mpakali, A.; Saridakis, E.; Harlos, K.; Zhao, Y.; Kokkala, P.; Georgiadis, D.; Giastas, P.; Papakyriakou, A.; Stratikos, E. LigandInduced Conformational Change of Insulin-Regulated Aminopeptidase: Insights on Catalytic Mechanism and Active Site Plasticity. J. Med. Chem. 2017, 60, 2963-2972.

(61) The PyMOL Molecular Graphics System, version 1.3; Schrödinger, LLC., 2010.

(62) Marelius, J.; Kolmodin, K.; Feierberg, I.; Aqvist, J. Q: A Molecular Dynamics Program for Free Energy Calculations and Empirical Valence Bond Simulations in Biomolecular Systems. J. Mol. Graphics Modell. 1998, 16, 213-225.

(63) Boukharta, L.; Gutiérrez-de-Terán, H.; Åqvist, J. Computational Prediction of Alanine Scanning and Ligand Binding Energetics in GProtein Coupled Receptors. PLoS Comput. Biol. 2014, 10, No. e1003585.

(64) Shamsudin Khan, Y.; Kazemi, M.; Gutiérrez-de-Terán, H.; Åqvist, J. Origin of the Enigmatic Stepwise Tight-Binding Inhibition of Cyclooxygenase-1. Biochemistry 2015, 54, 7283-7291.

(65) Jorgensen, W. L.; Maxwell, D. S.; Tirado-Rives, J. Development and Testing of the OPLS All-Atom Force Field on Conformational Energetics and Properties of Organic Liquids. J. Am. Chem. Soc. 1996, $118,11225-11236$.

(66) Jorgensen, W. L.; Chandrasekhar, J.; Madura, J. D.; Impey, R. W.; Klein, M. L. Comparison of Simple Potential Functions for Simulating Liquid Water. J. Chem. Phys. 1983, 79, 926-935.

(67) King, G.; Warshel, A. A Surface Constrained All-atom Solvent Model for Effective Simulations of Polar Solutions. J. Chem. Phys. 1989, 91, 3647-3661.

(68) Lee, F. S.; Warshel, A. A Local Reaction Field Method for Fast Evaluation of Long-range Electrostatic Interactions in Molecular Simulations. J. Chem. Phys. 1992, 97, 3100-3107.

(69) Ryckaert, J.-P.; Ciccotti, G.; Berendsen, H. J. C. Numerical Integration of the Cartesian Equations of Motion of a System with Constraints: Molecular Dynamics of N-Alkanes. J. Comput. Phys. 1977, $23,327-341$.

(70) Almlöf, M.; Brandsdal, B. O.; Åqvist, J. Binding Affinity Prediction with Different Force Fields: Examination of the Linear Interaction Energy Method. J. Comput. Chem. 2004, 25, 1242-1254.

(71) Almlöf, M.; Carlsson, J.; Åqvist, J. Improving the Accuracy of the Linear Interaction Energy Method for Solvation Free Energies. J. Chem. Theory Comput. 2007, 3, 2162-2175.

(72) Cheng, Y.; Prusoff, W. H. Relationship between the Inhibition Constant (K1) and the Concentration of Inhibitor Which Causes 50 per Cent Inhibition (I50) of an Enzymatic Reaction. Biochem. Pharmacol. 1973, 22, 3099-3108.

(73) Zwanzig, R. W. High-Temperature Equation of State by a Perturbation Method. I. Nonpolar Gases. J. Chem. Phys. 1954, 22, $1420-1426$. 